VERÓNICA HERNÁNDEZ DÍAZ

FACULTAD DE FILOSOFÍA Y LETRAS, UNAM

\title{
Los retablos de la capilla de Aránzazu de Guadalajara
}

MEDiados Del Siglo XVIII se construyó en Guadalajara, Jalisco, una
capilla dedicada al culto de Nuestra Señora de Aránzazu (fig. I). En la
actualidad es el único recinto de la ciudad que conserva sus retablos barrocos dorados, son tres y se distinguen por su elevada calidad artística. Una familia de ascendencia vasca, los Basauri, patrocinó la construcción; ello explica el protagonismo de la Virgen de Aránzazu y de otras imágenes religiosas originarias de la región vascongada. En este trabajo se exponen temas estilísticos e iconográficos de la capilla y sus retablos, y se narran sucesos relevantes de su historia, en particular los vínculos artísticos con obras de otro lugares de la región noroccidental mexicana a partir de similitudes formales y de las relaciones sociales y económicas que establecieron sus patrocinadores. Durante el siglo XVIII fue en esta región minera, agrícola y comercial donde el culto por la Virgen de Aránzazu tuvo mayor fuerza en la Nueva España. ${ }^{\text {I }}$

I. Con el entusiasta interés académico que le es característico, la doctora Bargellini revisó varias versiones de este texto; en cada ocasión recibí observaciones precisas para desarrollar y exponer la investigación; le estoy muy agradecida por su constante disposición y asesoría. También quiero dar las gracias al padre Leonardo Sánchez, director del Archivo Histórico del Convento de San Francisco, en Zapopan, Jalisco, por permitirme consultar el acervo, asimismo, a los religiosos y sacristanes encargados de la capilla de Aránzazu de Guadalajara, la capilla de la Virgen de La Candelaria, en Ameca, Jalisco, y, de la iglesia del Dulce Nombre de Jesús, en Amacueca, Jalisco, por las facilidades prestadas para fotografiar los retablos. 


\section{La capilla de Aránzazu y el antiguo convento de San Francisco}

En 1749 fray Pedro Íñigo Vallejo promovió la edificación de la capilla de Nuestra Señora de Aránzazu en Guadalajara; la continuó y culminó en I752 fray Tadeo de Vizcarra. ${ }^{2}$ Se construyó a expensas de Tomás Basauri, un rico hacendado y comerciante cuyo origen vasco determinó la dedicación del templo. ${ }^{3}$

La capilla de la Virgen de Aránzazu formó parte del desaparecido convento de San Francisco, el cual fue, después de la catedral, el espacio católico más importante de la Nueva Galicia. Fue fundado en I53I por fray Antonio de Segovia y durante las primeras décadas de su existencia tuvo varias sedes. Al principio se ubicó en Tetlán, una población ahora integrada a la zona metropolitana; en I542 Segovia lo trasladó a la recién fundada ciudad de Guadalajara y fue la primera obra religiosa que comenzó a edificarse en la capital neogallega en su cuarto y definitivo asentamiento, esta vez en el valle de Atemajac. Aquí, el convento se estableció primero en el barrio indígena de Analco, localizado al oriente del río San Juan de Dios (hoy ya extinto); un año después se mudó a la ribera poniente del río, en el cruce actual de la calle Héroes y la calzada Independencia. Finalmente, a causa de la humedad del sitio, en 1554 los frailes franciscanos fijaron su asentamiento un poco más hacia el norponiente, acercándose al centro de la ciudad, donde habitaba la población hispana. ${ }^{4}$

Con el paso del tiempo el convento llegó a ser un gran conjunto integrado por el templo principal y seis capillas, más otras construcciones y áreas diversas. Ahora sólo existe la iglesia de San Francisco de Asís con dos pequeñas capillas adosadas y cuyo interior ha sido modificado, y aparte la capilla de Aránzazu; el

2. Fray Luis del Refugio Palacio y Basave, Recopilación de noticias y datos que se relacionan con la milagrosa imagen de Nuestra Señora de Zapopan, y con su colegio y santuario, Guadalajara, Talleres de la Universidad de Guadalajara, 1942, t. I, p. I54; fray Ángel del Santísimo Sacramento Ochoa Velázquez, El convento de San Francisco de Guadalajara, 1554-1954, Guadalajara, Font, 1959, pp. I08-I09.

3. Biblioteca Pública del Estado de Jalisco (en adelante вPEJ), Real Cédula de Aprobación de la Cofradía de Aránzazu de Guadalajara, manuscrito 32 (5), f. 22v. El hallazgo de este documento, antes desconocido, es uno de los resultados de la presente investigación.

4. Los sucesos relativos a este convento fueron narrados originalmente hacia I650 en la crónica escrita por fray Antonio Tello: Libro segundo de la crónica miscelánea en que se trata de la conquista espiritual y temporal de la Sancta Provincia de Xalisco en el Nuevo Reino de la Galicia y Nueva Vizcaya y descubrimiento del Nuevo Mundo, notanda de Juan López, México, Porrúa, 1997. En fechas posteriores otros autores retoman su texto y añaden noticias que les fueron contemporáneas. 
I. Fachada de la capilla de la Virgen deAránzazu, Guadalajara, Jalisco, 2005.

Foto: V. H.

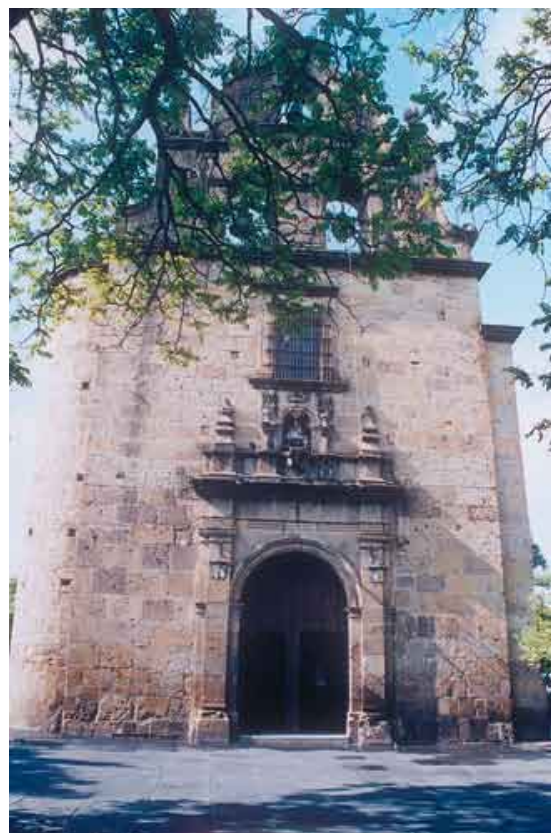

resto fue destruido a partir de 1860 , cuando se expidieron las leyes de Reforma. ${ }^{5}$ Entre los dos edificios que permanecen se abre la avenida I6 de Septiembre en su cruce con la calle Revolución, llamada Miguel Blanco a la altura de la capilla; su ubicación marca el límite sur del centro histórico tapatío.

Durante el periodo virreinal el convento de San Francisco desempeñó parte sobresaliente en la vida de Guadalajara. En el transcurso de más de dos siglos entre las puertas del convento y la cercana catedral se estableció la ruta más importante de las peregrinaciones devotas y de otros acontecimientos sociales. En los primeros años de I900, Luis del Refugio Palacio, un erudito franciscano con dotes de historiador, rescató del olvido sucesos relevantes de su comunidad y describió la composición monumental del convento tal como se encontraba hacia mediados del siglo XVIII. Se basó en documentos originales resguardados

5. Ochoa Velázquez, op. cit., p. 42. Este autor precisa las fechas de los primeros acontecimientos relativos al convento franciscano. Para elaborar su obra consultó algunos documentos originales del archivo franciscano, aunque en mayor medida se basa en lo escrito por fray Luis del Refugio Palacio. 
en el Archivo Histórico del Convento franciscano que se localiza en Zapopan, Jalisco; asimismo, en los relatos de viejos frailes y en sus propios recuerdos.

Nos dice que el conjunto era de cantera en su totalidad, cercado por una barda con arcos invertidos y con cuatro ingresos, uno hacia cada punto cardinal (fig. 2). El templo de San Francisco de Asís y la residencia conventual de los frailes ocupaban la sección sureste del extenso atrio; la cofradía de la Humildad y Paciencia de Cristo era la encargada del cuidado de la iglesia mayor. Las seis capillas distribuidas en el atrio se encomendaban a otras cofradías. La capilla del Santo Sepulcro fue la iglesia de los residentes de Analco y Mexicaltzingo, ambos barrios indígenas próximos; la atendía la cofradía del Santo Entierro; la capilla se insertaba entre el convento y el costado oriental del templo de San Francisco, y al igual que en éste su puerta principal se dirigía al Norte. En su planta alta estuvo la capilla del noviciado, exclusiva de los religiosos. Del lado norte del atrio, y visto por aquí, se ubicaban a la derecha la sacristía y la capilla de San Antonio de Padua, a cargo de los mulatos y de la cofradía del Dulce Nombre de Jesús; a la izquierda la capilla de la Tercera Orden o de San Roque, atendida por los vecinos españoles a través de la Venerable Orden Tercera; las portadas de estas dos capillas se enfrentaban y lucían espadañas. Entre ellas se abría el pórtico principal del atrio, que consistía en un arco grande coronado por una escultura de la Purísima Concepción flanqueada por las de san Francisco de Asís y san Antonio de Padua. Hacia el ángulo suroeste del atrio continuaba, como ahora la vemos, la capilla de Nuestra Señora de Aránzazu con su portada principal orientada hacia el norte; contaba con casa anexa para el sacristán y su respectiva cofradía. Entre los templos de Aránzazu y de San Francisco se encontraba el ingreso sur del convento. Unidas al muro poniente de la nave de la iglesia de San Francisco se ubicaban la capilla del Santo Cenáculo, encomendada a los cordíferos, y la del Calvario, después dedicada a Santa Ana. El convento albergaba también una serie de ermitas para la celebración del Vía Crucis empotradas en los muros exteriores de las capillas. Se sabe que el atrio sirvió como espacio abierto para la doctrina y enseñanza de los indígenas y funcionó como cementerio. Había cruz atrial, un claustro amplio de dos pisos con refectorio, enfermería, noviciado, celdas, biblioteca y huerto. ${ }^{6}$

6. Palacio, op. cit., pp. 87-I55 (el dibujo del conjunto que hizo nos da una idea clara de la monumentalidad del antiguo convento; el original de esta obra se preserva en el Archivo Histórico del Convento de San Francisco, en Zapopan); fray Rafael Cervantes, Aránzazu, suplemento de Jalisco en el Arte, Guadalajara, Departamento de Bellas Artes, vol. VIII, núm. I, invierno de I986-1987, p. IV. Este autor precisa, con el nombre actual de las calles, la extensión original del convento. 


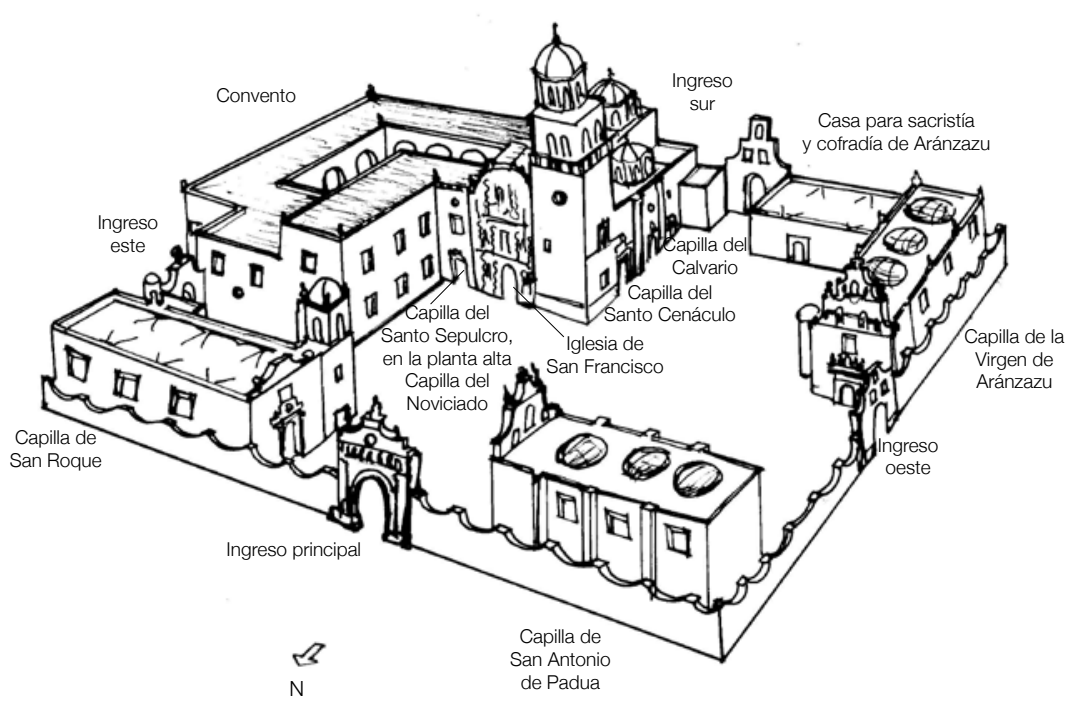

2. Reconstrucción del antiguo convento de San Francisco. Dibujo: Verónica Hernández, 2005, basado en Manuel Pérez Rosas et al., Templos de San Francisco y Aránzazu: investigación, estudio y restauración, Guadalajara, Universidad Autónoma de Guadalajara, 1973, s.n.p.

A partir de I860, con la Reforma, el convento de San Francisco fue destruido; sólo quedaron en pie la iglesia principal, cuyos retablos salomónicos ya habían sido sustituidos por otros neoclásicos en la década de I820, la capilla de Aránza$\mathrm{zu}^{7} \mathrm{y}$ las sencillas fachadas de las capillas anexas a la parte posterior de la torre de San Francisco, adosadas al muro poniente de la nave. Donde estuvo la capilla del Calvario o de Santa Ana, actualmente se encuentra la sacristía del templo de San Francisco y la del Santo Cenáculo, que también se llama capilla penitencial y del Santísimo Sacramento. A la derecha de ésta también se preserva una de las antiguas ermitas para la celebración del Vía Crucis.

Dentro del marco siguiente resulta significativo que ni la capilla de Aránzazu ni sus retablos hayan sido destruidos o modificados. Es conocido que el gusto predominante por el estilo neoclásico durante las primeras décadas del siglo XIX, así como la ejecución de las leyes de Reforma y el espíritu "modernizador" del xx ocasionaron que Guadalajara perdiera sus altares barrocos, se modificaran 
los interiores de los templos y se devastaran muchos de los edificios coloniales, tanto eclesiásticos como civiles. Acerca del antiguo convento cabe además resaltar que después de la iglesia de San Francisco de Asís le seguía en importancia la capilla de San Roque, donde realizaban ceremonias destacadas los comerciantes de origen español. Al parecer la destrucción del convento no siguió ningún plan de urbanización. A partir de estos datos sobresale la necesidad de análisis más extensos para conocer la razón de la permanencia de la capilla de Aránzazu y de sus retablos.

Cabe la posibilidad de que antes del periodo de Reforma los retablos no hayan sido sustituidos por considerarlos de factura reciente, aunque en el siglo XIX la familia Basauri, principal promotora de la capilla, ya había perdido su fortuna y era incapaz de costear otros de estilo neoclásico. No obstante, es más oportuno inferir que la ascendencia vasca de sus patrocinadores fue decisiva para evitar la pérdida de la capilla y sus altares originales. Fue la comunidad de origen vasco la que dominó la economía de Guadalajara y de las regiones aledañas que abastecían de productos diversos todo el noroeste novohispano durante los últimos cincuenta años del virreinato. ${ }^{8}$ La preeminencia financiera que lograron durante la etapa virreinal, a la par de su participación en los ámbitos político y social y su continuada importancia durante la Reforma, pudieron impedir el derrumbe de la obra que representaba su tradición religiosa, origen y sentido de comunidad.

Una muestra de la importancia que alcanzó el culto a la Virgen de Aránzazu entre la sociedad tapatía y del predominio económico de los vascos la constituyen las primeras publicaciones hechas en la ciudad. En I793 se introdujo la imprenta a Guadalajara. Acababa de fallecer su renombrado obispo fray Antonio Alcalde, promotor de grandes obras pías en la comunidad, y a él se dedicó el texto Honras fúnebres a fray Antonio Alcalde. En tanto, de modo simultáneo apareció la Novena de la milagrosa imagen de Nuestra Señora de Aránzazu, por un especial devoto de esta soberana reyna. ${ }^{9}$

8. Acerca de este poderío económico escribe Jaime Olveda, "Juan Manuel Caballero: integración y desintegración de una fortuna”, en Amaya Garritz (coord.), Los vascos en las regiones de México, siglos XVI-XX, México, Universidad Nacional Autónoma de México/Ministerio de Cultura del Gobierno Vasco/Instituto Vasco-Mexicano de Desarrollo, 1996, t. II, p. 53.

9. Impresos mexicanos del siglo XVI (los incunables), México, Centro de Estudios de Historia de México Condumex, 1995, p. 72 (catálogo de exposición). 


\section{El culto a la Virgen de Aránzazu}

El milagro de Aránzazu

La región vasca en la península ibérica se ubica en la costa cantábrica, en los límites con Francia e incluye las provincias de Álava y Guipúzcoa, el señorío de Vizcaya y parte del de Navarra. Según narra la tradición, las cofradías de las provincias vascongadas acostumbraban reunirse los días $\mathrm{I}^{\circ}$ de mayo en la aldea de Ulibarri para llevar cirios-ofrendas. La alternativa de portar o no los cirios sobre los hombros causó discordia entre los pobladores y entonces hubo encuentros violentos que provocaron la huida de los labradores a las montañas. Sin nadie que sembrara, proliferaron las hambrunas y se agudizaron durante una época de sequías que azotó la región. Ante estas circunstancias y con el propósito de imponer la paz, en 1469 la Virgen se le apareció a un pastor humilde llamado Rodrigo Balzategui. Al verla, éste expresó en lengua vascuence: Aránzazu, voz que en castellano significa "Tú entre espinas", pues fue así como la Virgen se le reveló.

El milagro ocurrió donde colindan las provincias de Guipúzcoa, Álava y Navarra. Después del suceso, el pastor se dirigió al pueblo principal de Oñate; luego de escucharlo, los dirigentes fueron al lugar de la aparición y le fabricaron un techo de ramas a la Virgen. Cuando regresaron a Oñate empezó a caer la ansiada lluvia. En agradecimiento trajeron la imagen a Oñate, pero más de una vez desapareció para volver al lugar original del milagro. Finalmente decidieron construirle un santuario en el sitio del prodigio y fundaron su correspondiente cofradía. Muy pronto se convirtió en el destino de numerosas peregrinaciones y los vascos olvidaron sus diferencias anteriores, se unificaron y divulgaron el culto de Aránzazu. ${ }^{\mathrm{IO}}$

\section{La difusión de su culto}

Los vascos desempeñaron un papel fundamental en la conformación social, política y económica de la Nueva España. Su presencia data de los primeros años de

ıo. Clara García Ayluardo, "El milagro de la Virgen de Aránzazu: los vascos como grupo de poder en la ciudad de México”, en Clara García Ayluardo y Manuel Ramos Medina (coords.), Manifestaciones religiosas en el mundo colonial americano, México, Universidad Iberoamericana/ Condumex/Instituto Nacional de Antropología e Historia, 1997, pp. 33I, 332; Cervantes, op. cit., pp. II y III. 
la conquista. ${ }^{\text {II }}$ En el caso de las tierras occidentales fue un conquistador vasco quien fundó Guadalajara en su cuarto y definitivo asiento. ${ }^{12}$ A partir del siglo XVII su emigración se incrementó, a la vez que ocuparon importantes puestos administrativos y eclesiásticos. El sentido de asociación que produjo el milagro de Aránzazu en la población vasca europea continuó en la que se hallaba en América. En territorio novohispano la primera capilla bajo su advocación fue construida en 167I en la ciudad de México, dentro del convento de San Francisco. Diez años después los vascos-novohispanos constituyeron su cofradía y promovieron la creación en el mismo convento de una capilla nueva dedicada a su Virgen. ${ }^{13}$

En la Nueva España los medios impresos fueron útiles para difundir la religiosidad vasca. En I686, en la ciudad de México, Juan de Luzuriaga, comisario general de los franciscanos, escribió una obra donde relata el milagro de Aránzazu y la historia de la fundación del santuario en la región vascongada española. La publicación fortaleció a la cofradía y extendió el poder de la imagen de Aránzazu a través del concepto de lealtad y unidad entre los descendientes vascos. ${ }^{\mathrm{I}}$ La nueva capilla de Aránzazu del convento franciscano de la ciudad de México se inauguró el 2I de noviembre de I688. ${ }^{5}$ Hacia fines del siglo XIX la destrucción del convento incluyó la capilla de Aránzazu; no obstante su desaparición, se conoce la suntuosidad del templo y de sus retablos barrocos. ${ }^{16}$

En honor a Aránzazu se erigieron altares y capillas en otras partes del país, en especial en la región noroccidental, donde la población de origen vasco era abundante. ${ }^{17}$ En Guadalajara esta devoción se advierte en la primera mitad del siglo XVIII, cuando fue creada la primera capilla dedicada a su culto en la ciudad. No sabemos con exactitud cuándo se construyó, pero la parroquia de Nuestra

II. García, op. cit., p. 335 .

I2. Se llamaba Cristóbal de Oñate y era entonces el tercer gobernador de la Nueva Galicia, Tello, op. cit., p. 301.

I3. Elisa Luque Alcaide, La cofradía de Aránzazu de México (1681-I799), Pamplona, Eunate, 1995, pp. 36 y 37 .

I4. El libro se titula Paranimpho celeste: Historia de la mistica zarza, milagrosa imagen y prodigiofo santuario de Aranzazu de religiosos observantes de N. Seraphico Padre San Fco. en la provincia de Gvypuzcoa de la región de Cantabria, García, op. cit., p. 332.

I5. Luque, op. cit., pp. 37 y 38.

16. García, op. cit., p. 342.

17. Cervantes, op. cit., p. III. Este autor hace un recuento de las capillas de Aránzazu que existen en Zacatecas y en San Luis Potosí. 
Señora del Pilar, a la cual se anexaba, comenzó a edificarse en i7i8 y dos años después se abrió al culto. ${ }^{\mathrm{I}}$ Hacia 1742 Mota Padilla menciona que este recinto dedicado a Aránzazu estaba en servicio y cuenta de su participación en la vida religiosa de la ciudad. También informa que el vasco Esteban de Arreburu fue quien aportó el capital para su construcción. ${ }^{19} \mathrm{Al}$ final del siglo xix la parroquia del Pilar fue completamente reconstruida y la capilla de Aránzazu se eliminó. En el techo del pequeño vestíbulo que ahora funciona como atrio del templo está inscrita la fecha de i884, tal vez el año de la culminación de las obras. En el área donde se veneró a Aránzazu se ofrece culto a san Nicolás de Bari. ${ }^{20}$

\section{La capilla de Aránzazu de Guadalajara: en medio del amor y los negocios}

Durante los años de 1700 los vascos se contaban entre los mineros más renombrados de la Nueva España. Ello les permitió constituir el partido vizcaíno dentro del consulado de la ciudad de México. En tanto, su dominio del comercio transatlántico y pacífico les dejó utilidades enormes y capital líquido que invirtieron en empresas mercantiles y mineras, así como en la adquisición de tierras. ${ }^{21}$ Como parte de un acucioso estudio sobre la economía agrícola de Guadalajara y sus zonas aledañas durante el siglo XviıI, el investigador Eric van Young describe el desarrollo de la familia que financió la construcción del templo de Aránzazu en el convento franciscano de Guadalajara. ${ }^{22}$ A partir de los datos proporcionados por Van Young, Jorge Olveda añade noticias de la familia

I8. Luis Enrique Orozco Contreras, Iconografia mariana de la Arquidiócesis de Guadalajara, Guadalajara, s.e., I954, vol. II, pp. 367-369.

19. Matías de la Mota Padilla, Historia del Reino de la Nueva Galicia en la América septentrional, Guadalajara, Instituto Jalisciense de Antropología e Historia, 1973, pp. 308-310. La crónica de este abogado y fraile franciscano data de alrededor de I742. Se basó en la obra no publicada aún de fray Antonio Tello. Además, Mota relata sucesos que le fueron contemporáneos.

20. Ignacio Dávila Garibi, Recopilación de datos para la historia del convento de San Francisco de Guadalajara, Guadalajara, General "El Radio", 1926, p. 32. El templo de Nuestra Señora del Pilar se localiza en el cruce de las calles Francisco I. Madero y Enrique González Martínez.

2I. García, op. cit., pp. 355 y 356.

22. Eric Julian van Young, "Rural Life in Eighteenth Century Mexico: the Guadalajara Region, I765-I820", tesis doctoral, Berkeley, Universidad de California, 1978. El autor consultó fuentes originales localizadas en archivos diversos. Esta obra fue publicada por el Fondo de Cultura Económica con el título La ciudad y el campo en el México del siglo XVIII. La economía rural de la región de Guadalajara, $1765-1820$. 
80

VERÓNICA HERNÁNDEZ DÍAZ

Basauri y aclara el papel que desempeñaron los vascos en la región noroccidental durante el virreinato. ${ }^{23}$ En tales estudios se sustenta de modo principal la información siguiente en torno a la historia de los Basauri.

La familia Basauri, los orígenes

El linaje de los Basauri comienza con Gregorio, un comerciante originario de la villa de Oñate, Guipúzcoa, establecido en Guanajuato a principios del siglo XviII. Fue en esta centuria cuando la Nueva Galicia logró consolidar su poder político y económico a través del fortalecimiento de su vocación comercial. Guadalajara, su capital, se convirtió en el centro rector de las actividades administrativas y mercantiles en el noroeste de la Nueva España. La abundancia de la región atrajo a numerosos emigrantes, muchos de ellos vascos, como lo ejemplifica Gregorio Basauri, quien se casó en Guanajuato y en poco tiempo conformó una riqueza mediana. En I720, en Piedra Gorda (hoy Manuel Doblado, Guanajuato) nació su hijo Tomás, ${ }^{24}$ quien heredó la fortuna familiar y las dotes de comerciante de su padre que le permitieron acrecentar rápidamente su patrimonio.

\section{Tomás Basauri, el ascenso}

Olveda ha señalado las alianzas matrimoniales como una de las formas de integración de grandes fortunas durante el periodo colonial; eran el medio por el que, además de las personas, se unían capitales y extensas porciones de tierra. Así, después de la muerte de su padre, Tomás Basauri contrajo nupcias en 1747 con María Magdalena Iriarte, hija de Manuel Francisco Iriarte, el notario y administrador de la aduana, quien le proporcionó una dote de 4000 pesos. En esta época los bienes de Basauri consistían en la hacienda de Frías, situada cerca de Manuel Doblado, Guanajuato, ${ }^{25}$ y valuada en 52000 pesos, más un legado

23. Jaime Olveda, "La familia Basauri: poder e influencia vasca en Guadalajara", en IV Seminario de Historia de la Real Sociedad Vascongada de los Amigos del País, México, Real Sociedad Vascongada de los Amigos del País/Ministerio de Cultura, I993, t. I, pp. I68-I86.

24. Es probable que su madre fuera Nicolasa Elizondo, según Cervantes dueña de la hacienda de Tolimán ubicada en las cercanías de Zapotitlán, al sur de Jalisco, citando a Domingo E. Cerrillo, Memorias de mi pueblo, San Diego de Alejandría, Jal., León, 1969, op. cit., p. VII. La población de Manuel Doblado se encuentra entre León y La Piedad, en una zona colindante con Jalisco.

25. La hacienda de San Nicolás de Frías se localiza entre la presa de Jalpa y San Pedro Piedra Gor- 
de 8400 pesos por parte de una hermana muerta en la ciudad de México. Tales recursos le permitieron aportar el dinero suficiente para que en 1749 se iniciara la construcción de la capilla de Aránzazu. Con ello, Tomás Basauri dio muestra del tradicional fervor vascongado por la Virgen y el sentido de nación que éste les confería; asimismo, manifestó su riqueza, la cual, destinada a obras pías, suscitaba prestigio social. Cabe hacer notar que en ese año falleció su esposa, lo que igualmente pudo motivar la notable materialización de su religiosidad. De este matrimonio Basauri tuvo un hijo llamado José Tomás Mauricio.

En I752 la edificación de la capilla estaba concluida; al año siguiente Basauri adquirió una casa en el exclusivo barrio de San Francisco, donde vivía su suegro. Aun cuando ya desde los primeros años de la década de 1750 la fortuna de este vasco-novohispano prosperó rápidamente, su éxito financiero no se consolidaría sino hasta años después de su llegada a Guadalajara. Por tanto, llama la atención que en forma temprana dedicara gran cantidad de sus bienes a la fabricación y ornamentación de la capilla de Aránzazu.

Basauri fue un negociante hábil y versátil, que contaba con propiedades diversas y se dedicaba a giros comerciales distintos: su hacienda de Frías surtía de harina a las minas de Zacatecas y de Guanajuato, mientras él se dedicaba al comercio en Guadalajara. En esta ciudad se asoció en tres ocasiones para establecer tiendas de venta al mayoreo y en cada caso aportó la mayoría del capital efectivo. En I749 su primer socio fue otro vasco, Agustín de Arzubialde; de 1753 a 1755 se unió con Joseph de Fox, y en 1756 fundó una nueva compañía mercantil con José de Sarobe, un comerciante modesto de origen vasco.

En ese último año Tomás volvió a casarse, esta vez con María Magdalena Cid de Escobar, una criolla originaria de Aguascalientes. Para esta fecha el patrimonio de Basauri constaba de la hacienda de Frías y propiedades en Guadalajara, cuyo valor total se calculaba en 190000 pesos, es decir casi el triple de lo que tenía en la década anterior. De este matrimonio nacieron cuatro hijos: José Joaquín Mauricio, José Ignacio María, Joseph Xavier Eusebio y María Josefa.

En 1759 Tomás Basauri fue nombrado alcalde ordinario y reelecto al año siguiente. La participación en la política local era favorable para su economía personal, pues le permitía agilizar sus negocios e intervenir en el diseño de los reglamentos reguladores del mercado urbano. Después de más de una década,

da, poblaciones llamadas hoy Jalpa de Cánovas y ciudad Manuel Doblado, respectivamente, Cervantes, op. cit., p. VII. 
en I773, Basauri acrecentó considerablemente sus bienes. En esa fecha murió el hijo de su primer matrimonio - José Tomás Mauricio-y recibió la herencia que Manuel Francisco Iriarte, el abuelo materno, tenía destinada para su nieto. El legado de Iriarte ascendía a 63007 pesos. $^{26}$

\section{La fundación de la cofradía}

A la construcción de la capilla de Aránzazu siguió el establecimiento de su respectiva cofradía. Previo permiso de la Real Audiencia y del obispo fray Antonio Alcalde, el 3 de julio de 1774 los naturales y descendientes de las provincias de Vizcaya, Guipúzcoa, Álava y Navarra que residían en Guadalajara se reunieron en el templo de Aránzazu con el fin de tratar los medios más oportunos para fundar la cofradía. A la junta asistió el padre guardián del convento, fray Juan Vezino, con quien acordaron los estatutos de gobierno de la cofradía. El 28 de marzo del año siguiente los vascongados informaron ante notario sus fines, las capitulaciones convenidas y especificaron que a Tomás Basauri se debía la conclusión de la capilla y su ornamentación. El conjunto de estos datos se incluye en todas las actas que tratan la fundación de la cofradía que he localizado durante la investigación y que antes eran desconocidas. ${ }^{27}$ Conviene subrayar que los documentos no son claros en cuanto al número de retablos que existían en ese tiempo en la capilla, debido a que en general se les refiere como altares. No obstante, en el primer acuerdo oficial, es decir la firma de la escritura compromiso entre los solicitantes de la cofradía y el padre guardián del convento, efectuada el 28 de marzo de 1775 , se anota "el retablo del altar". ${ }^{28}$

En otra junta ante notario el día 17 del siguiente mes de junio, los vascos tapatíos comunican haber solicitado el permiso real para establecer la cofradía, que se tramitaría por medio de la cofradía de San Ignacio de Loyola de Madrid. Ésta presentaría la petición en el Real Consejo de Indias y solicitaría en la Corte de Roma la concesión a la cofradía de Aránzazu de Guadalajara de las mismas indulgencias que gozaban la cofradía de San Ignacio de Madrid y la de Aránza-

26. Van Young, op. cit., pp. 278-280; Olveda, "La familia Basauri...”, op. cit., pp. I69-17I.

27. Realicé la indagación documental en archivo entre marzo, abril y mayo de 1998 en la Biblioteca Pública del Estado de Jalisco y el Archivo de Instrumentos Públicos del Estado de Jalisco, y en junio y julio de 1999 en el Archivo Histórico de Zapopan del Convento de San Francisco.

28. Archivo de Instrumentos Públicos del Estado de Jalisco (en adelante AIPej), protocolo de Antonio de Berroa, I757-I782, vol. 19, ff. I35r-I38r. 
zu de México. ${ }^{29}$ Mientras tanto, el I9 de abril, el obispo de Guadalajara, fray Antonio Alcalde, recibió las constituciones de la cofradía y las destinó para su revisión al promotor fiscal del obispado, el licenciado Pedro Díaz León. Luego de examinar su apego a las leyes del reino, éste dio su visto bueno el I3 de mayo; en seguida, el día I6, el obispo Alcalde aprobó las constituciones. De todo lo anterior fue enterado el rey, quien finalmente consintió la fundación de la cofradía el Is de julio de $1776 . .^{30}$

Entre los solicitantes aparecen funcionarios eclesiásticos y del ayuntamiento de Guadalajara; además de Tomás Basauri se encuentran Baltasar Colomo, quien era deán de la Catedral; Manuel Colón de Larreategui, arcediano; Manuel Domingo de la Fuente, prebendado; Domingo del Barco, contador juez oficial de la Real Hacienda; José Lorenzo de Corta, ensayador balanzario; Francisco Arriesola, clérigo presbítero; Agustín Velázquez Lorea, Juan de Zárate y Bedona, Juan Ángel Ortiz y José de Sarobe, este último socio de Tomás Basauri. ${ }^{31}$

El acta de fundación consta de trece constituciones; en ellas se conviene la sujeción de la capilla al obispado de la ciudad, en tanto su administración estaría a cargo de la cofradía y no habría intervención del padre guardián del convento franciscano. Quedó establecida la celebración de festividades dedicadas a la Virgen de Aránzazu: su fiesta principal sería el domingo infraoctavo de la natividad de la Virgen, que es el mismo día dedicado al Dulce Nombre de María; y se pagarían las limosnas por tales celebraciones y otras ceremonias que realizaran en la capilla el padre guardián del convento y sus frailes. Asimismo se fijó el procedimiento para elegir a las autoridades de la cofradía y se precisaron detalles sobre la administración de la capilla y sus fondos; se estipuló el oficio de misas en honor a Tomás Basauri después de su muerte y la ayuda que se ofrecería para el entierro en la capilla de los cofrades que fallecieran sin bienes suficientes. La solicitud de los vascos para integrar en forma exclusiva el cuerpo de la cofradía fue la única constitución rechazada. En su lugar se asienta que debido a las circunstancias debía recibirse a los vasallos del rey de ambos reinos. ${ }^{32}$

29. AIPEJ, ibid., ff. 265r-266v.

30. вPEJ, Real cédula de aprobación de la cofradía de Aránzazu de Guadalajara, op. cit., ff. $2 \mathrm{Ir}-24 \mathrm{~V}$.

3I. AIPEJ, op. cit., f. 265 r.

32. вреJ, Real cédula de aprobación de la cofradía de Aránzazu de Guadalajara, op. cit., ff. $2 \mathrm{Ir}-24 \mathrm{v}$. 
Volviendo a los sucesos de la familia Basauri, Van Young y Olveda relatan que Tomás reafirmó su ascendencia vasca cuando ingresó, en 1776, a la Real Sociedad Vascongada de los Amigos del País. ${ }^{33}$ Acerca de su actividad empresarial: hasta 1780 diversificó sus inversiones y otorgó una gran cantidad de créditos a mercaderes y funcionarios, entre ellos a su compañero cofrade Joseph Lorenzo de Corta. A la par que ampliaba sus negocios, Tomás Basauri nombraba representantes en diversas partes del virreinato para el manejo de sus bienes y la resolución de pleitos civiles y criminales en los que se veía inmiscuido cuando sus deudores incumplían sus obligaciones, o sus mismos agentes y administradores lo estafaban. Esta clase de conflictos se prolongaban varios años; algunos continuaron después de su muerte, ocurrida entre i780 y 178I. Para esta fecha el prestigio social y el éxito económico de su familia estaban consolidados. Aun así, sería con los hijos de Tomás, especialmente José Ignacio y María Josefa, con quienes se alcanzaría el máximo apogeo.

\section{Los descendientes de Tomás Basauri, auge y decadencia}

En 178I la viuda de Basauri, María Magdalena Cid de Escobar, disolvió la sociedad formada por su marido con José Sarobe, quien era ya un destacado empresario y además alcalde ordinario de Guadalajara. En los primeros años de la década de 1780, María Magdalena compró dos haciendas de la zona de Cuquío, Jalisco: Ixcuintla y La Higuera. Por su parte, José Ignacio Basauri, su segundo hijo, contrajo matrimonio con Mariana Villazón, nieta de Pedro Álvarez Cantón, un antiguo minero de Bolaños dueño de la hacienda de Atequiza, una de las más importantes de la región de Guadalajara. En 1782 José Ignacio compró esta hacienda y la de Miraflores, en la localidad de Cuquío.

Pocos años después, en I786, María Josefa Basauri, al igual que su hermano, contrajo matrimonio con uno de los miembros de la oligarquía tapatía. Se llamaba José María de Castañeda y Medina, poseía las haciendas Cerro Gordo

33. Van Young, op. cit., pp. 280-284 ; Olveda, "La familia...”, op. cit., pp. I7I-I84. De dichas fuentes provienen los datos históricos de este apartado y del siguiente; la información proporcionada por Van Young y Olveda se complementa con lo que aportan las actas de fundación de la cofradía de Aránzazu. 
y Milpillas, situadas en la región de los Altos, y era el titular del mayorazgo de González Castañeda.

Se ha hecho notar que la familia Basauri incrementó su riqueza por medio de alianzas matrimoniales y diversas transacciones, pero ante todo lo consiguió actuando como grupo en la administración de sus bienes. Es de esta manera como el declive inició en $\mathrm{I787}$, cuando los Basauri dividieron la herencia paterna y decidieron liquidar los negocios (una tienda en Guadalajara y otra en Tepic) y repartir las ganancias. Éstas incluían una gran cantidad de deudas en su favor; sin embargo, la mayoría fue irrecuperable. A José Joaquín le correspondió la hacienda de Frías; las de Miraflores y Atequiza quedaron en poder de José Ignacio y su madre, mientras que María Josefa recibiría anualidades por parte de los coherederos. Del otro hijo, Joseph Xavier, no hay noticias, por lo que es probable que hubiera muerto.

Todo indica que la venta de las tiendas redujo la liquidez de la familia. En I790 José Joaquín hipotecó la hacienda de Frías para obtener un préstamo; aunque en el mismo año José Ignacio compró la hacienda de La Huerta, en Poncitlán, y se integró al cabildo, posteriormente pidió préstamos al Claustro de la Universidad y al Seminario de San José para cubrir sus gastos. En I795, un año después de quedar viudo, José Ignacio tomó el hábito franciscano y solicitó un préstamo a José Sarobe, el antiguo socio de su padre, con el fin de saldar su deuda con el Seminario.

La ruina de la familia Basauri se produjo en forma definitiva a partir de la muerte de José Ignacio, ocurrida entre I800 y I80I. María Magdalena vendió las haciendas de Ixcuintla y La Higuera en I802, en tanto que María Josefa y su esposo vendieron terrenos de sus haciendas de Cerro Gordo y Milpillas; en 1806 los descendientes de José Ignacio se deshicieron de la hacienda de Miraflores. En I809 falleció María Josefa y en I813 su madre. Para I8I5 José María Castañeda, el viudo de María Josefa, y sus hijos se declararon en quiebra y acusaron a José Joaquín Basauri de retrasar la repartición de la herencia materna. Hacia el primer cuarto del siglo XIX, la cuarta generación de los Basauri no fue capaz de incrementar lo que había quedado del patrimonio de sus antepasados. ${ }^{34}$

Al parecer fueron José Ignacio y su familia quienes se hicieron responsables de los gastos de la capilla de Aránzazu después de la muerte de María Magdale- 
na Cid de Escobar en I8I3. Aun así, la crisis financiera de la familia se advierte claramente en el cuidado que dejaron de proporcionar a la capilla que había construido y sustentado Tomás Basauri. Consta en libros de carta-cuenta del convento de San Francisco, entre I8I2 y I8I5, que les fue imposible solventar sus deberes como cofrades: José Joaquín debía las misas celebradas para sus difuntas esposa y madre, las funciones titulares en honor a la Virgen de Aránzazu, las misas que se cantaban el día 8 de cada mes de julio, los oficios de sermones, los novenarios, las procesiones, aniversarios, oficios y tres años de capellanía, todo lo cual sumaba I 554 pesos. 35

Los descendientes de José Joaquín pudieron conservar la hacienda que dio origen a la riqueza de la familia Basauri: la de Frías; todavía en 1877 la poseían ${ }^{36}$ y quizás les proporcionó recursos suficientes para saldar sus deudas con el convento, puesto que en los libros de carta-cuenta posteriores a I8I5 que consulté no se menciona a los Basauri como deudores, incluso en I855 se anota que Rafael Basauri donó seis manteles. ${ }^{37}$ Según fray Rafael Cervantes, éste administraba hacia I854, junto con su hermano Manuel, la hacienda de Frías, ${ }^{38}$ pero al igual que el resto del patrimonio familiar esta propiedad se perdió y la familia Basauri desapareció por completo de la oligarquía de Guadalajara. Desde la segunda mitad del siglo XIX los religiosos franciscanos asumieron las funciones de la cofradía: la preparación de las ceremonias ofrecidas a la Virgen de Aránzazu, el mantenimiento del edificio y su abastecimiento. Fray Luis Palacio escribe al respecto:

Los patrones tiempo ha que sólo suministraban la exigua cantidad de cincuenta pesos para ayuda de los costos del novenario. Las reparaciones - y alguna muy costosa con motivo de los temblores de 1875 - ya tampoco las han hecho los patronos; por lo cual, y con no sostener al capellán, sacristán, vino, cera, etc. [...] es visto haber cesado en sus derechos. 39

35. Archivo Histórico de Zapopan (en adelante AHZ; este archivo pertenece al convento franciscano que reside en la localidad), libro de carta-cuenta, convento de San Francisco de Guadalajara, I782-I8I5, carta-cuenta celebrada el 30 de abril de I8I5, ff. 80v-86r.

36. Olveda, "La familia Basauri...", op. cit., p. I83.

37. AHz, libro carta-cuenta de I8I6, carta-cuenta celebrada el 5 de mayo de I855, ff. 93r-97r, f. $95 \mathrm{r}$.

38. Cervantes, op. cit., p. VII, apuden Domingo E. Cerrillo, op. cit.

39. Palacio, op. cit., pp. 153 y I54. 


\title{
La capilla de Aránzazu y sus retablos: descripción, estilo e iconografía
}

\author{
El edificio
}

La sobria fachada de la capilla de Nuestra Señora de Aránzazu fue construida con cantera amarilla; presenta espadaña y dos portales de configuración sencilla (fig. I). En la portada principal se observan dos pilastras dóricas que flanquean el acceso, el cual es un arco de medio punto moldurado; las pilastras sostienen un entablamento con cornisa y están rematadas por adornos piramidales. Sobre la cornisa, al centro, se encuentra un pequeño nicho con peana que aloja una escultura en bulto de la Virgen de Aránzazu; se le representa cargando al niño Jesús y con un cetro en su mano derecha; está parada sobre una especie de tronco y la acompañan el pastor Rodrigo Balzategui y un grupo de ovejas. Arriba de la moldura superior de la hornacina hay una concha con un motivo vegetal. En cada lado del nicho hay una diminuta columna ornamentada con ramas floridas al modo salomónico, sobre la que se mira el relieve de un jarrón con flores. Al motivo central de la Virgen le sigue en ascenso la ventana del coro, de forma rectangular y enmarcada.

La espadaña tiene dos cuerpos; en el inferior hay dos vanos en forma de arcos de medio punto con barandales; en los huecos, gruesas vigas sostienen las campanas. Flanqueando estos dos vanos, hay pilastras y dos grandes medallones con personajes de medio cuerpo en relieve. Una gruesa moldura, con roleos en los extremos, delimita esta sección. Sólo un vano-campanario, similar a los anteriores, aparece en el segundo cuerpo de la espadaña; está al centro y a sus lados se observan pilastras y luego otros dos medallones con relieves. La parte superior de la espadaña está enmarcada por una moldura que forma espirales y curvas, y termina a los lados en pedestales que sostienen remates esféricos; la culminación del conjunto es una cruz.

Los cuatro personajes que encierran los medallones son fundadores de órdenes religiosas. En la parte inferior izquierda de la espadaña vemos a santo Domingo de Guzmán, el creador de la Orden de Predicadores y divulgador de la devoción del Rosario; a la derecha está el fundador de la Orden de los Frailes Menores, san Francisco de Asís. En la sección superior se encuentran san Ignacio de Loyola a la izquierda y san Felipe Neri a la derecha; el primero es de origen vasco y fundó la Compañía de Jesús; el segundo creó la Congregación del Oratorio.

En el muro oriental de la capilla sobresale el cubo cilíndrico de la escalera que conduce al coro y al campanario. En la pared se distribuyen tres contrafuer- 

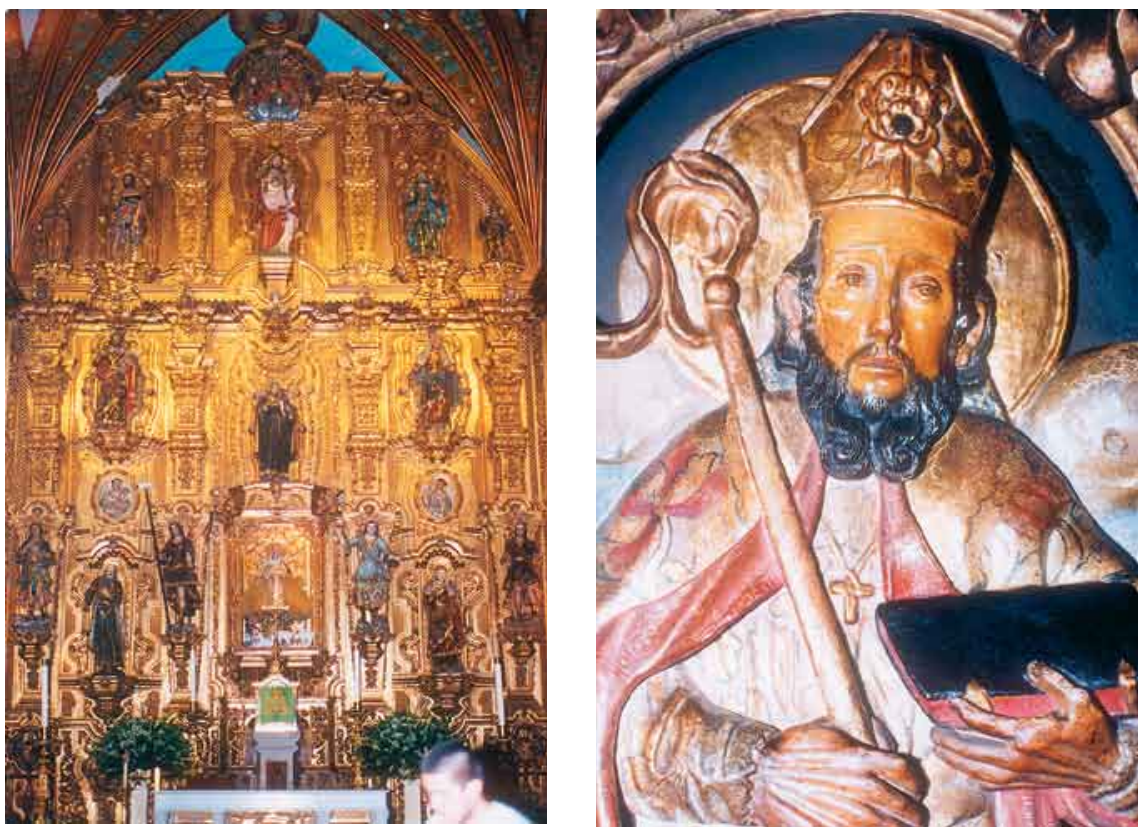

3. Retablo de la capilla de la Virgen de Aránzazu: a) vista general; b) san Ambrosio, I998.

Foto: V. H.

tes y tres ventanas. El ingreso es similar al de la fachada principal; en este caso, el pequeño nicho sobre la cornisa resguarda a san José con el niño Jesús. En la portada del costado poniente sólo se miran tres contrafuertes y en lo alto de sus paramentos tres ventanas. La parte posterior del edificio es lisa, sin vanos ni decoración.

La planta interior de la capilla mide 31.2 por $8 \mathrm{~m} . .^{\circ}$ Tres arcos de medio punto, con pilastras dóricas unidas por una cornisa corrida, soportan las bóvedas del edificio y dividen el espacio en cuatro tramos. Las bóvedas están decoradas por nervaduras, elemento típico de la arquitectura colonial de la región, y pinturas que aparentemente datan del siglo xx y repiten motivos geométricos, vegetales, roleos y símbolos de la orden franciscana. El coro descansa en un arco de cinco centros. En el segundo tramo, a la izquierda, se localiza la entrada lateral y

40. Javier Huízar Zuno, "La capilla de Aránzazu”, Presencia Universitaria, suplemento de $E l$ Informador, Guadalajara, 4 de agosto de I998, p. 9. 


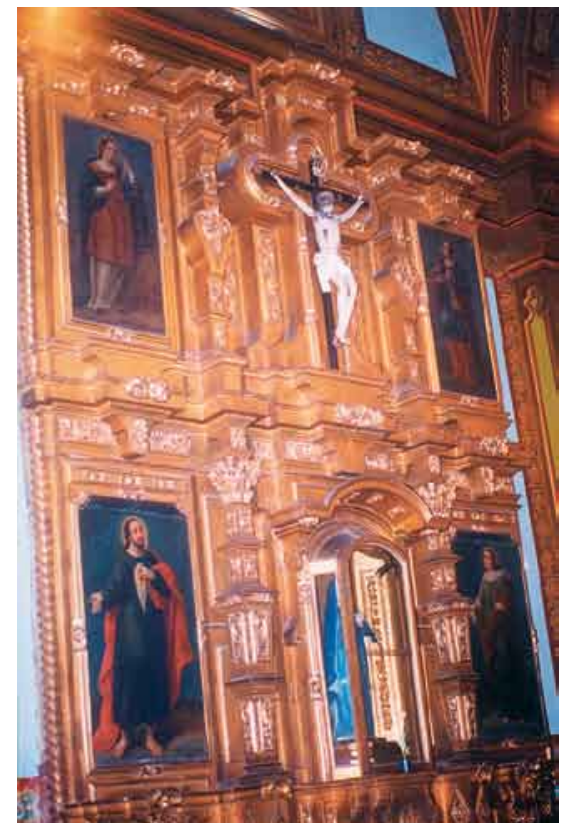

Foto: V. H

frente a ella un cuadro de gran formato que presenta al árbol doctrinario de san Francisco. Esta pintura, de excelente factura, data de fines del siglo xviI y está firmada por Arellano. En el tercer tramo sobresalen del lado izquierdo el retablo dedicado al Calvario de Cristo y a la derecha el de san José. En la sección última vemos en los costados pequeñas puertas que dan a los guardarropas o utileros, $y$ en los muros dos cuadros del siglo xx con episodios de la vida de san Francisco de Asís. Al fondo, cubriendo toda la pared del ábside, está el retablo mayor con la Virgen de Aránzazu dentro de un fanal.

\section{Los retablos}

Los tres altares de la capilla reciben sus nombres de las imágenes principales que ostentan; en torno a ellas se configuran los programas iconográficos. Los retablos de la Virgen de Aránzazu, de Cristo y de san José están dorados y pertenecen a las modalidades del barroco estípite y anástilo. En su composición se aprecian elementos que caracterizan la evolución del estilo estípite durante el siglo Xviı y su paso a la eliminación de las columnas. 
Según lo apunta Sergio Zaldívar, el barroco estípite en la arquitectura del valle de Atemajac presentó un desfase en cuanto al seguimiento de las corrientes artísticas en general. Señala que aun cuando la columna estípite se hizo común en el país, prácticamente no llegaron a realizarse en las construcciones de Guadalajara, ya que continuaron elaborándose las columnas salomónicas o las toscanas con ornamentos en el primer tercio..$^{41}$ La portada de la capilla de Aránzazu es un ejemplo de lo anterior, con sus columnas dóricas y de un estilo distinto al de sus retablos. Sin embargo, se debe subrayar que las evidencias conocidas no permiten saber qué tan populares fueron los retablos estípites en la región; lo único cierto es que, de los 26 retablos barrocos que se conservan en Jalisco, menos de la mitad pertenecen a esta modalidad. ${ }^{42}$

En la capilla de Aránzazu son notables las diferencias formales entre los retablos. El tamaño, el diseño, el tipo y la complicación de los ornamentos, así como la calidad de las tallas y sus estofados, permiten asegurar que fueron ejecutados en diferentes etapas y suponer que distintos artistas trabajaron en su manufactura. No obstante, en el caso de los retablos mayor y de san José existen elementos similares que podrían sugerir su diseño por parte de un mismo arquitecto.

Resulta obvio que el retablo mayor fue el primero en realizarse, tanto por estar dedicado a la Virgen de Aránzazu como por su composición con rasgos propios de la primera etapa del barroco estípite. Tal vez el siguiente en fabricarse fue el de san José, hacia las últimas décadas del siglo XviII, cuando el estilo estípite deviene en la ostentosa modalidad llamada anástila, distinguida por el desarrollo de los interestípites y el uso de formas rococó. Además de su complicada elaboración, destaca porque las esculturas que lo integran exhiben la talla y el estofado más finos entre las imágenes de la capilla. En comparación con los anteriores, el altar dedicado a la Pasión de Cristo se mira austero; siguiendo la opinión de Ignacio Gómez, ${ }^{43}$ los estípites son los únicos elementos que lo identifican con tal estilo; su estructura se acerca al neoclasicismo y por ello es posible ubicarlo en las postrimerías del mismo siglo XviII. Otra hipótesis acerca de su sencillez formal es que efectivamente este retablo fue el último en erigirse en la capilla, pero no se terminó de ornamentar con relieves adosados a causa de la crisis financiera de los Basauri y se decidió dorarlo con sus paredes casi lisas y

4I. Sergio Zaldívar, "Arquitectura religiosa del siglo Xviı en el valle de Atemajac", Artes de México, Guadalajara, núms. 94-95, año XVI, 1967, pp. 66-73.

42. Esta información me la proporcionó, por medio de una entrevista en mayo de 1998 , el arquitecto Ignacio Gómez Arriola, con base en la investigación que prepara: "Los retablos barrocos de Jalisco". 43. Comunicación personal, mayo de 1998. 
decorarlo con lienzos, cuya factura solía ser de menor costo; así, la figura principal de Cristo es la única escultura.

\section{El retablo de la Virgen de Aránzazu}

La estructura del altar mayor se compone de sotabanco, banco, un cuerpo muy alto y remate (fig. 3a). Está dorado por completo y es el más grande de los tres retablos del templo. La imagen titular, una figura de vestir, destaca al centro dentro de una elaborada vitrina. El resto de los personajes religiosos que lo integran son esculturas y relieves policromados y estofados.

El marco del conjunto es una moldura acompañada por una hilera de adornos vegetales y roleos entrelazados. Los cuatro largos estípites que sirven de apoyo dividen el retablo en tres calles. De los estipos se proyectan peanas que soportan arcángeles de pie. Entre los estípites hay pilastras-nicho con esculturas y medallones ovalados moldurados que exhiben altorrelieves de santos. En el banco hay otra serie de medallones, cuatro lobulados y dos ovalados, con figuras de medio cuerpo en relieve. En la parte central del banco se halla la puerta que conducía al sagrario; muchos de los relieves que la decoraban se han perdido, pero conserva en los extremos superiores dos esculturas de angelitos que resguardan la entrada.

Una cornisa pronunciada separa el cuerpo y el remate: está decorada en sus partes frontal e inferior con múltiples rostros de ángeles. El remate se inscribe en un arco de medio punto con formas poligonales y roleos; presenta dos estípites ubicados arriba de los soportes centrales del cuerpo inferior. Entre dichos estípites y a los lados se miran tres pilastras-nicho con esculturas y en los extremos dos esculturas pequeñas. Culmina el altar, una figura de medio cuerpo en altorrelieve. La decoración general del retablo la componen relieves de vegetales, conchas, roleos y cabezas policromadas de ángeles. Un toque distintivo lo da el diseño reticulado en los espacios que sirven de fondo.

A partir de sus rasgos formales, cabe advertir dos grupos de imágenes religiosas. Uno lo forman las esculturas pequeñas ubicadas en los extremos del remate, las figuras adosadas y los relieves de los medallones del cuerpo y del banco del altar (fig. 3b); en ellos se aprecian las tallas y los estofados más finos en comparación con el resto de las esculturas de tamaño natural que integran la obra. El segundo grupo lo conforman estas últimas obras; aunque están estofadas y policromadas en diferente medida, presentan el mismo patrón de rigidez corporal; algunas se miran repintadas. Las calidades distintas entre las figuras 
podrían explicarse si consideramos que fray Luis Palacio apunta que este retablo carece de su imaginería original. ${ }^{44}$ De ser así, el primer grupo mencionado sería el remanente de los originales. Acerca de la parte restante, es factible suponer que en algún momento del siglo xix, cuando la familia Basauri había dejado de cubrir la manutención de la capilla, se intercambió con figuras de otras capillas del convento, que se habrían perdido a raíz de su destrucción. Otra posibilidad es que resultaron afectadas por el temblor ocurrido en 1875 .

Por lo que toca a la iconografía del retablo, en la calle central sobresale la Virgen de Aránzazu, cargando al niño Jesús y acompañada del pastor a quien se le apareció. Arriba vemos a san Francisco de Asís, fundador de su orden; lleva amarrado a su mano izquierda un crucifijo y en la otra deja ver uno de los estigmas que recibió. Como teólogos que fundamentan los principios de la Iglesia, en el banco del altar se ubican los Doctores o Padres de la Iglesia y dos de los máximos representantes de la escolástica; los libros que portan simbolizan sus escritos. De izquierda a derecha están san Agustín, obispo fundador de su orden, quien viste mitra y capa, y sobre el libro que carga se asienta la maqueta de un templo; san Gregorio Magno, quien fue papa y por ello usa tiara, y cuyo atributo personal es una paloma, símbolo del Espíritu Santo, quien le sirve de inspiración; santo Tomás de Aquino, dominico que ostenta en el pecho un sol de oro como manantial que irradia la luz de la verdad; san Buenaventura, considerado el segundo fundador de la orden franciscana; san Jerónimo, traductor del Antiguo Testamento, a quien se identifica por la corneta que anuncia la salvación del cielo en el momento del juicio, y san Ambrosio, quien aparece con indumentaria episcopal, capa, mitra y báculo (fig. 3b); los escolásticos son el dominico Tomás y el franciscano Buenaventura.

En el cuerpo del retablo, los arcángeles que se ven a la izquierda son san Rafael, con el distintivo pescado en la mano, y san Miguel, con una lanza y en el pecho el sol y la luna. Entre ellos, frente a una pilastra-nicho, aparece san Joaquín, padre de la Virgen, representado como un anciano. Arriba de esta figura, en un medallón, está el santo franciscano Antonio de Padua, con su característico lirio en la mano, y sobre éste, el esposo de la Virgen, san José, abrazando a su hijo Jesús; parece faltarle en su mano derecha una vara florida, otro de los elementos que lo caracterizan.

Aun cuando los dos arcángeles en la calle tercera carecen de atributos, se pueden identificar como Gabriel y Uriel, ya que de los siete arcángeles conocidos lo 

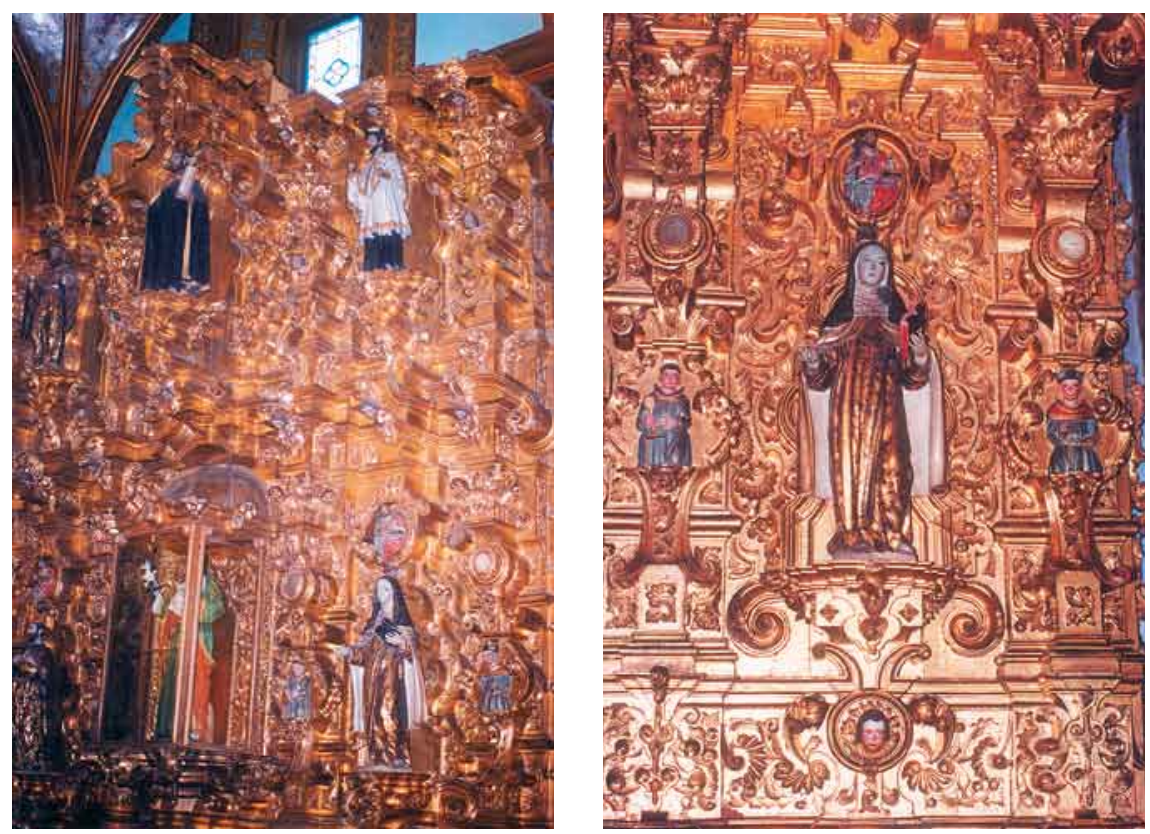

5. Retablo de San José: a) vista general; b) calle derecha, santa Teresa de Jesús, I998. Fotos: V. H.

común es que sólo se representen los cuatro mencionados. Santa Ana, la madre de la Virgen, aparece en medio de los dos y no lleva atributos, pero es constante su representación cercana a su esposo san Joaquín. Sobre ella, en un medallón paralelo al del margen izquierdo, se encuentra el franciscano san Bernardino de Siena, quien difundió la devoción al Nombre de Jesús, cuyo monograma se inscribe en el ostentorio que lleva. Más arriba se mira a santa Isabel, madre de Juan el Bautista y prima de la Virgen, y se le reconoce por su vejez.

En el remate, en la calle central, está la imagen del Sagrado Corazón de Jesús; su factura reciente lo presenta con telas encoladas; viste túnica blanca con manto rojo como símbolo del sufrimiento, muestra estigmas en las manos y permite ver su corazón. A la izquierda se mira a san Juan Bautista y a la derecha al apóstol san Juan Evangelista. Es probable que las pequeñas esculturas ubicadas en los extremos sean el beato Juan Duns Escoto y a la derecha la venerable María de Jesús de Ágreda. Ésta muestra su corazón como símbolo del amor por Dios; debido a este atributo y a su ajuar, la figura puede también identificarse como santa Clara de Asís. No obstante, en la iconografía franciscana era frecuente que 
Juan Duns Escoto y María de Jesús de Ágreda estuvieran asociados, pues ambos son franciscanos famosos que defendieron a la Inmaculada Concepción de la Virgen.

Dios Padre es la figura que corona el retablo en su representación tradicional como anciano, vestido de rojo: con la mano derecha bendice y con la izquierda sostiene una esfera azul que simboliza el universo.

\section{El retablo de Cristo}

Este altar lateral es el más sencillo y pequeño de la capilla y el único que incluye pinturas (fig. 4). La estructura es dorada, presenta sotabanco, banco y dos cuerpos de igual tamaño; dos estípites exentos dividen el conjunto en tres calles. Los dos estípites del primer cuerpo tienen capitel corintio y los del segundo dórico. Los relieves ornamentales son escasos y consisten en motivos vegetales y roleos; en el banco éstos se miran encerrados en formas geométricas. Una moldura helicoidal angosta enmarca el retablo.

Su imaginería presenta personajes correspondientes a la Pasión y la muerte de Cristo. En la calle central del segundo cuerpo sobresale un relieve moldurado en forma de cruz, con un crucifijo de madera. Palacio escribe que el Cristo es de cartón, aunque tal vez sea de pasta de caña, y perteneció a la desaparecida capilla de San Antonio del antiguo convento franciscano. Añade que él mismo lo colocó en el retablo de la capilla de Aránzazu. ${ }^{45}$ Debajo del Cristo se observa dentro de una vitrina a la Virgen en su advocación de La Dolorosa. La escultura es reciente y viste con túnica y manto azul de telas encoladas.

Alrededor de las esculturas de Cristo y de la Virgen se disponen cuatro lienzos sin firma que datan de fines del siglo XvirI. Cada uno exhibe una figura que ocupa casi todo el largo del cuadro y lleva anotado su nombre en la parte inferior; el fondo de la pintura es plano con horizonte bajo. Los cuatro personajes llevan en sus manos un pañuelo en señal de duelo. De abajo hacia arriba se miran a la izquierda san Juan Evangelista y santa María Salomé; a la derecha, santa María Magdalena y santa María Cleofas. El centro del banco lleva inscrito en relieve el monograma IHs, representación del nombre de Jesús y abreviación de las palabras latinas Iesus, Hominum Salvator (Jesús, salvador de los hombres). 
6. Retablo de la Virgen del Rosario,

Templo del Rosario, Sinaloa.

Foto: Archivo Fotográfico IIE-UnAM.

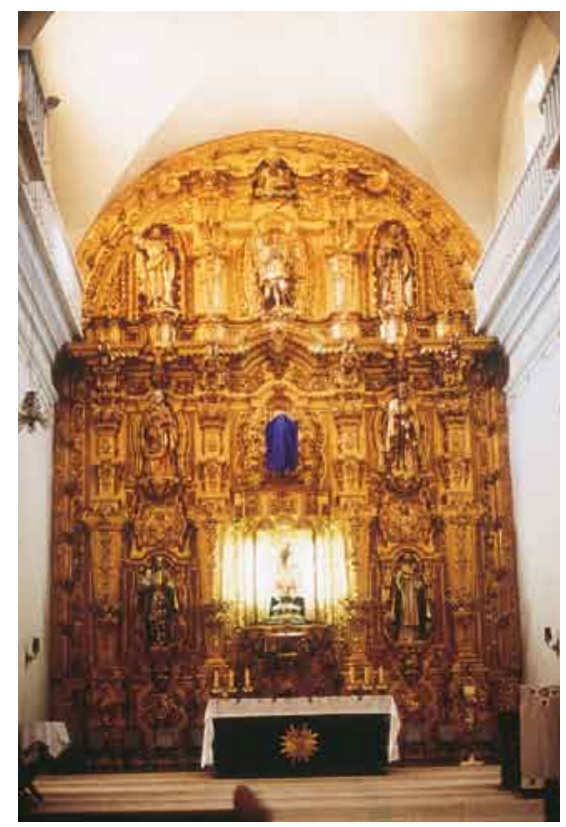

\section{El retablo de San José}

Es el que más se proyecta de la pared, sobre todo en la parte superior; es anástilo y está profusamente decorado y dorado por completo (fig. 5a). Se compone de sotabanco, banco y dos cuerpos; gruesas cornisas poligonales que con ondulaciones separan los cuerpos del retablo y delimitan la sección superior.

En cada cuerpo, cuatro pilastras con capitel corintio marcan las tres calles del retablo. En la central destaca un fanal donde se aloja san José; en relación con las otras presentes en los altares, su escultura es de factura más reciente. Viste con ropa de tela, al igual que la imagen de Aránzazu del retablo mayor. A su alrededor se observan cinco esculturas de tamaño natural de diversos religiosos, dos en el primer cuerpo y tres en el segundo. Están paradas sobre peanas y les sirven de marco las molduras que sobresalen de las calles. Arriba de las dos que se disponen en la sección primera se miran relieves de figuras de medio cuerpo que resaltan de marcos ovalados y con roleos. En el nivel medio de las cuatro pilastras del primer cuerpo hay otras figuras pequeñas en altorrelieve. En total son seis y se hallan enmarcadas por vistosas formas vegetales. Estas imágenes relevadas y las esculturas, excepto la de san José, están estofadas y policromadas. 
96 VERÓNICA HERNÁNDEZ DÍAZ

A la ornamentación del retablo se añade un abundante número de roleos rococó y de rostros infantiles policromados que voltean hacia distintas direcciones; motivos vegetales se extienden por todo el conjunto y hay varios agnus enmarcados en molduras ovaladas.

Entre las figuras religiosas sobresalen dos santos jesuitas, cuyo origen vasco explica su presencia en el retablo y en la capilla de Aránzazu. Uno de ellos es san Francisco Javier, nacido en Navarra; se ubica en la calle lateral que vemos a la izquierda y su actitud es distintiva: se abre la sotana y muestra su corazón en llamas, símbolo de su ardiente amor por Dios. Las figuras en altorrelieve que lo rodean son, a la izquierda, un santo franciscano que tal vez sea Juan de Capistrano; arriba, san Juan Evangelista, también presente en los otros dos retablos, que aquí sostiene el libro que representa su obra y lo acompaña un águila que lleva en el pico un recipiente pequeño con la tinta que sirvió al santo para escribir el cuarto Evangelio; a la derecha quizá esté san Buenaventura de Bagnorea, quien lleva bonete, el tipo de sombrero usado por clérigos de jerarquías diversas y por los doctores.

En la calle derecha se mira a santa Teresa de Jesús, carmelita española reformadora de su orden; fue escritora mística y recibió el título de doctora de la Iglesia; signo de ello es el libro abierto que sostiene (fig. 5b). La figura en altorrelieve a la izquierda es un franciscano que lleva una custodia con la inscripción IHS; puede ser Bernardino de Siena o Pascual Bailón. Arriba de santa Teresa, está san Juan Bautista y, a la derecha, un franciscano, tal vez san Buenaventura o el beato Juan Duns Escoto.

San Ignacio de Loyola es el segundo vasco jesuita del retablo; su posición es claramente protagónica, pues se encuentra en la sección central superior de la calle más decorada y sobresaliente. Loyola nació en Guipúzcoa y fundó la Compañía de Jesús; sostiene el libro de las Constituciones de su orden, donde se lee ad majorem Dei gloriam y el monograma IHs, emblemático de los jesuitas. A la izquierda vemos a san Agustín, con la indumentaria propia de su orden, de color negro y con mangas anchas; como obispo, luce cruz pectoral. El estofado de su vestidura es similar al de las imágenes de san Francisco Javier y santa Teresa de Jesús; sin embargo, su rostro está muy deteriorado. Del lado derecho, san Juan Nepomuceno porta su tradicional capa de armiño; es un mártir defensor del secreto sacramental y santo protector de la buena fama, lo cual serviría en parte para explicar su presencia, ya que los jesuitas se encargaron de promover su culto en la Nueva España. El conjunto está rematado por una sobresaliente cornisa moldurada que se quiebra y presenta espirales en los costados. 
7a. Retablo de la Virgen de la Candelaria, capilla de la ex hacienda

El Cabezón, vista general, 1999. Foto: V. H.
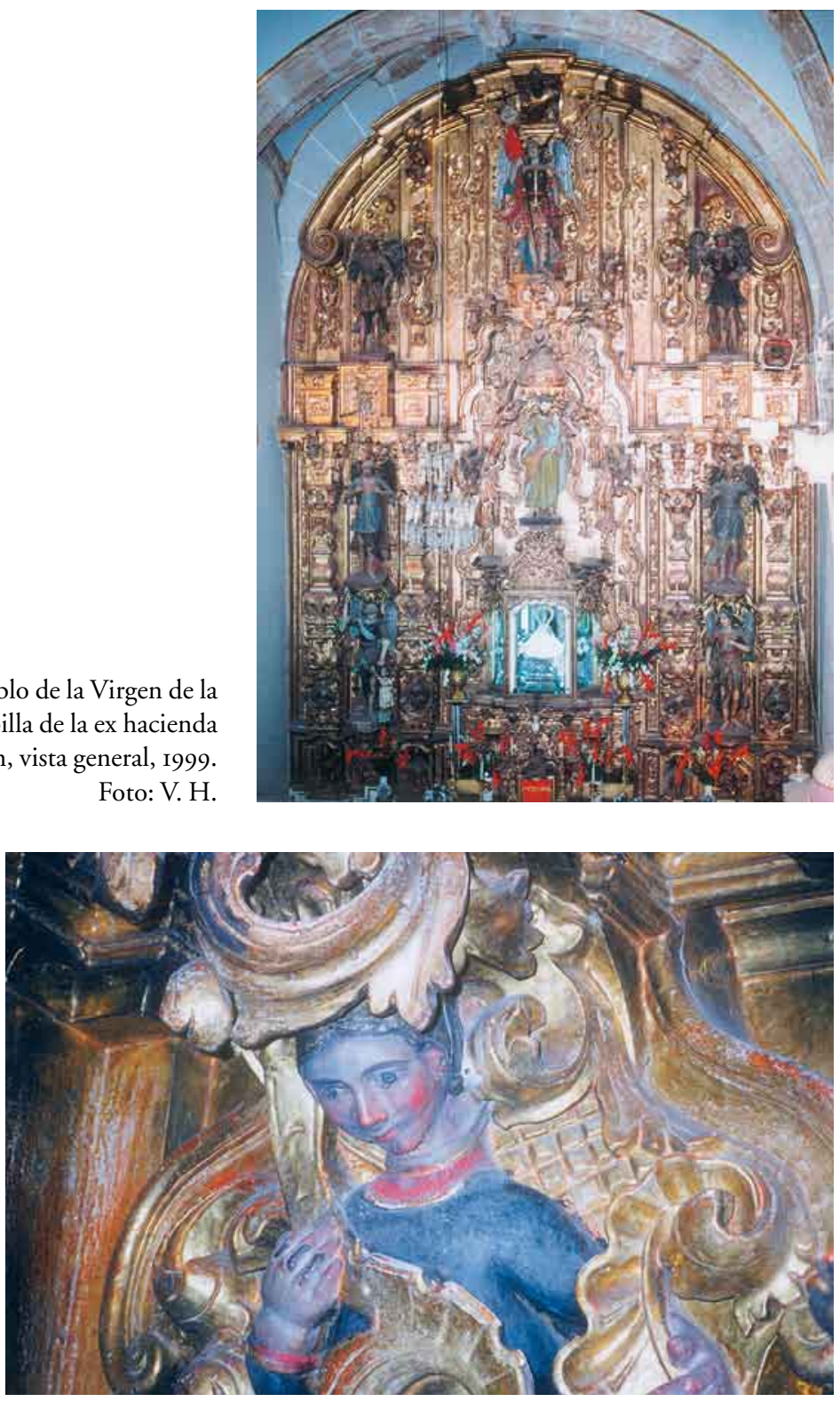

7b. Retablo de la Virgen de la Candelaria, capilla de la ex hacienda El Cabezón, detalle, 1999. Foto: V. H. 
Sin exponer argumentos específicos, Joseph Baird ha fechado el retablo alrededor de $1775 .{ }^{46}$ Pudo realizarse poco tiempo después, ya que para el mismo año, en uno de los documentos del establecimiento de la cofradía de Aránzazu, sólo se anota "el retablo del altar".

\section{Similitudes y diferencias entre los retablos}

La información histórica consultada revela que los tres retablos de la capilla datan de la segunda mitad del siglo xvirI. Por sus características formales, se podría pensar que su ejecución ocurrió en distintos momentos dentro de este periodo: el retablo mayor y el de la Pasión de Cristo son de estilo barroco estípite; el de san José es anástilo.

Ciertas semejanzas sugieren relaciones entre los artistas retablistas que crearon el de Aránzazu y el de San José. Parte de la imaginería del primero, la que puede considerarse original, muestra rasgos plásticos y calidad del entallado y estofado similares al retablo de San José. Recordemos que fray Luis Palacio indica que el retablo de Aránzazu carece de sus figuras originales. A partir de la movilidad de las esculturas autónomas, cabe aplicar esta información a las figuras de tamaño natural no sujetas a la estructura del altar. De tal modo, ahora suponemos como originales a las numerosas figuras en altorrelieve (por ejemplo, fig. 3b), las dos pequeñas esculturas adosadas de la puerta que conducía al sagrario y las exentas que ocupan los extremos laterales del remate. Si lo anterior es cierto, es posible inferir que el mismo taller o artistas entalladores y estofadores crearon por lo menos las figuras humanas en ambos retablos.

Los retablos de la capilla de Aránzazu no son estrictamente de dimensiones enormes, pues el mayor mide alrededor de $\mathrm{I} 2 \mathrm{~m}$ de altura; aun así producen en el espectador una sensación envolvente. Ello se debe a la pequeñez de la capilla y a los efectos lumínicos en el dorado de los retablos. En ninguna otra iglesia tapatía puede apreciarse con tal magnitud el esplendor del barroco. Aun cuando existen otras construcciones con fachadas notables, como Santa Mónica y San Felipe Neri, sólo la capilla de Nuestra Señora de Aránzazu ha preservado su interior casi como lucía en el siglo XVIII, con obras de arte de calidad reconocida, legadas por una antigua familia vasca a partir de su devoción religiosa y sentido nacionalista.

46. Joseph Baird, Los retablos del siglo XVIII en el sur de España, Portugal y México, Rebeca Barrera (trad.), México, Universidad Nacional Autónoma de México-Instituto de Investigaciones Estéticas, 1987 , pp. 202 y 203. 


\section{Consideraciones acerca del estudio de los retablos de la capilla de Aránzazu}

Hasta el momento todos los escritos referentes a la capilla de Aránzazu y al desaparecido convento franciscano de Guadalajara se basan principalmente en la obra del historiador fray Luis del Refugio Palacio. En 1904 inició su Recopilación de noticias y datos que se relacionan con la milagrosa imagen de Nuestra Señora de Zapopan y con su colegio y santuario. Palacio falleció en I94I y su obra se publicó por primera vez al año siguiente. El libro recoge historia oral, información que consultó en manuscritos originales del periodo novohispano y asimismo la experiencia personal del autor. Cabe anotar que él mismo se encargó de las reparaciones hechas a la capilla de Aránzazu a raíz del temblor ocurrido en I875.

Después de la destrucción del convento de San Francisco, gran parte del acervo de su biblioteca fue a dar al fondo del cercano lago Agua Azul, hoy ya extinto. ${ }^{47}$ De lo que pudo rescatarse, una parte se guarda en la Biblioteca Pública del Estado de Jalisco y otra en el Archivo Histórico del convento franciscano de Zapopan. En este último sitio, Palacio recabó su información escrita. ${ }^{48}$ Desafortunadamente, en dicho Archivo no existen documentos específicos sobre la capilla de Aránzazu, sus retablos y cofradía, y tampoco los hay del resto de las capillas que integraban el convento. ${ }^{49}$ La mayoría de los libros referentes al antiguo convento que se conservan tratan de la administración de la iglesia principal y casi la totalidad de ellos data de los siglos XVIII y XIX..$^{\circ}$ De modo particular, en los libros de cartacuenta de la iglesia de San Francisco sólo he encontrado referencias mínimas y dispersas sobre la capilla de Aránzazu, así como de miembros de su cofradía y de la familia Basauri. Los datos, ya anotados páginas atrás, indican las deudas con-

47. José Cornejo Franco, "La calle de San Francisco", en José Cornejo Franco, Obras completas, Guadalajara, Gobierno del Estado de Jalisco, 1985, vol. I, p. 76.

48. Fray Luis del Refugio Palacio fungió como secretario del convento. Debido a sus funciones, en I9I4 elaboró un inventario de la iglesia y sacristía de San Francisco. Resulta interesante que para ello siguió el modelo tradicional de los inventarios hechos durante la colonia, tanto en composición como en caligrafía.

49. Gracias al apoyo de los frailes encargados del Archivo Histórico del convento franciscano de Zapopan, pude realizar esta indagación en junio y julio de 1999. De la información relativa al convento sólo se resguardan dos inventarios, uno de 1826 y otro de I9I4 —este último realizado por fray Luis del Refugio Palacio- acerca de la iglesia de San Francisco de Asís, el cual contempla las capillas adosadas a su costado izquierdo: la del Santo Cenáculo y la de Santa Ana.

50. Conviene agregar que el Archivo Histórico del Convento franciscano de Zapopan cuenta con libros de distintos conventos pertenecientes a la Provincia de la Nueva Galicia; algunos de estos documentos son del siglo XVI. 
IOO

VERÓNICA HERNÁNDEZ DÍAZ

traídas por los descendientes de Tomás Basauri con el convento por concepto de mantenimiento y de celebración de actos religiosos en el templo de Aránzazu.

Por otra parte, en la Sección de Fondos Especiales de la Biblioteca Pública del Estado de Jalisco, acerca de la capilla de Aránzazu únicamente se preservan la Real cédula de aprobación de la cofradía de Aránzazu, la copia manuscrita delas actas que se levantaron ante el notario, donde se describe el proceso del establecimiento de la cofradía, y los documentos de una queja presentada por cofrades de Aránzazu al padre guardián del convento en noviembre de I79I. Dicha queja trata de la celebración de las misas por parte de los religiosos del convento y fue denegada; además, fue el motivo que originó la transcripción de las actas originales de la fundación de la cofradía.

Con base en los resultados obtenidos, se puede concluir que los libros de gobierno de la capilla de Aránzazu se han perdido. La indagación documental es una parte fundamental para acreditar de modo puntual la fecha de factura de los retablos y de su imaginería, así como el nombre de los artistas-autores. Como dicha vía se ha agotado por ahora, es conveniente seguir la investigación a través de las relaciones formales con otros retablos. A partir de ello cabría realizar búsquedas en archivos de iglesias que preserven altares semejantes a los de Aránzazu. De tal suerte, a continuación se aborda un estudio interregional de arte con la intención de profundizar en la historia de la capilla de Aránzazu. Se exploran algunas relaciones artísticas a través de similitudes formales y de lo que se conoce de la historia social y económica de la familia Basauri.

\section{Los vínculos artísticos a través de las relaciones sociales y económicas}

\section{El retablo de Nuestra Señora del Rosario, El Rosario, Sinaloa}

El templo de Nuestra Señora del Rosario se localiza en el sitio del mismo nombre, en Sinaloa. Su retablo es muy parecido en estructura y ornamentación al retablo mayor de la capilla de Aránzazu (fig. 6)..$^{\text {I }}$

En 1565 , en la provincia de Chametla, el conquistador vasco Francisco de Ibarra fundó la población del Rosario. Por su actividad minera, desde I747 el Real de Minas de Nuestra Señora del Rosario llegó a ser el asentamiento más rico de

5I. La doctora Clara Bargellini me proporcionó la información inicial acerca de la similitud entre dichos retablos. 
todo el noroeste novohispano. Otro vasco, en este caso un minero nacido en El Rosario y llamado Francisco Xavier Vizcarra, fue quien patrocinó la construcción de la iglesia del Rosario, y asimismo de las otras dos iglesias barrocas que hay en Sinaloa, las de Concordia y Copala; estas tres ciudades integraban la próspera región minera de lo que fue Nueva Vizcaya. ${ }^{52}$

Francisco Xavier Vizcarra nació alrededor de $1727 ;{ }^{33}$ según consta en cédula real, en $\mathbf{7 7 2}$ recibió el título de primer marqués de Pánuco; entre sus méritos se anota la fabricación y el adorno de la iglesia del Rosario, con un gasto de 50000 pesos. Se ignora cuándo se inició la construcción, pero había cierto avance en I758, año inscrito en la fachada lateral del templo. Por su parte, el templo de la Concordia pudo terminarse en $\mathrm{I} 785$, de acuerdo con la fecha que se lee en la sacristía; acerca de la iglesia de Copala se ha dicho que el marqués la costeó después de la anterior. ${ }^{54}$ Se deduce que estas obras son posteriores a la capilla

52. Al parecer, El Rosario cambió de sede en 1655 debido al descubrimiento y la explotación de importantes minas de plata: Elisa Vargaslugo, "El arte barroco en el territorio de Sinaloa”, en José Guadalupe Victoria et al., Regionalización en el arte. Teoría y praxis, México, Gobierno del Estado de Sinaloa/Universidad Nacional Autónoma de México-Instituto de Investigaciones Estéticas, I992, pp. 65-68.

En tanto, el templo del Rosario tuvo una ubicación diferente de su sede actual en esta misma localidad: las condiciones del terreno, socavado por la explotación minera, le ocasionaron serios daños. Su traslado — piedra por piedra—y reconstrucción sucedieron de 1932 a I96I. Del edificio sólo la fachada quedó de modo idéntico a la original, pues en el resto hubo cambios de diseño y de materiales. El retablo mayor también fue desarmado e integrado a la reconstrucción. En el primer sitio se conservó parte de la antigua parroquia: José Carlos Zazueta Manjarrez, "Historia de un monumento que se negó a morir. La iglesia de Nuestra Señora del Rosario, El Rosario, Sinaloa”, Anales del Instituto de Investigaciones Estéticas, México, Universidad Nacional Autónoma de México-Instituto de Investigaciones Estéticas, núms. 74-75, primavera-otoño de 1999, pp. 257-269.

53. Van Young, op. cit., p. 302.

54. Hay referencias sobre un templo primitivo en El Rosario, con un retablo anterior al que ahora nos ocupa: se sabe que en I73I se hizo la dedicación de la iglesia y del retablo a Nuestra Señora del Rosario y a Santo Domingo, mas entonces éste figuraba en un lienzo dentro del mismo altar; ahora se trata de una escultura, Vargaslugo, op. cit., pp. 65-68.

En el Libro registro de la segunda visita de Pedro Tamarón y Romeral, obispo de Durango (introducción y notas de Clara Bargellini y Chantal Cramaussel, paleografía de Delia Pezzat Arzave, México, Siglo XXI, 1997), se nos informa que el templo de Copala estaba en proceso de construcción en 1767 , y únicamente la sacristía se había terminado; en ese mismo año, a la iglesia parroquial del Rosario sólo le faltaba la bóveda y contaba con buen trabajo de cantería y varios retablos. En tanto, la suntuosa iglesia de San Sebastián Concordia no se había construido aún, ibid., pp. XXIII. El libro de la visita del obispo Tamarón y Romeral nos aporta también valiosos datos sobre los inventarios de estas iglesias; sin embargo, no hay datos sobre su patrocinador, Francisco Xavier Vizcarra. 

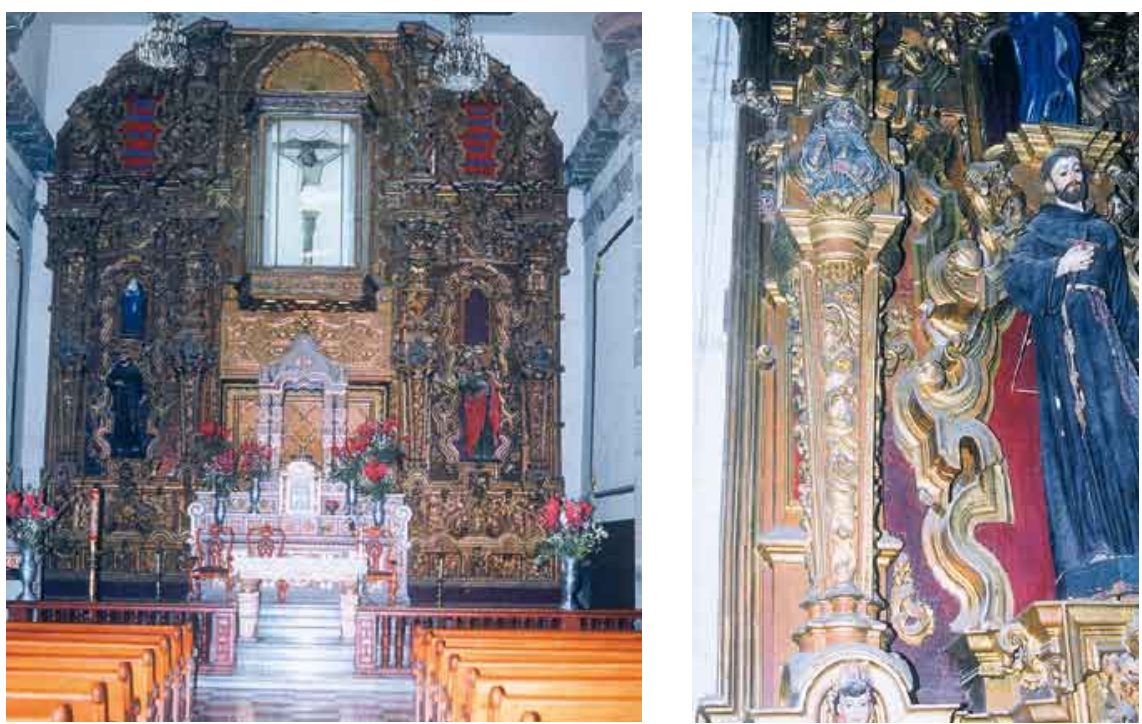

8. Retablo del Dulce Nombre de Jesús, Amacueca, Jalisco: a) vista general; b) estipo de la calle izquierda, 1999. Fotos: V. H.

de Aránzazu, la cual se edificó entre 1749 y I752; sus retablos, en particular el mayor, debieron realizarse en fechas próximas.

$\mathrm{Al}$ igual que el retablo de Nuestra Señora de Aránzazu, el del Rosario es dorado, compuesto por banco, un cuerpo muy alto y remate. Rasgos distintivos de ambos son los relieves reticulados que sirven de fondo al conjunto y la ornamentación con relieves de diseños vegetales, conchas, roleos y cabezas de ángeles. Como en Aránzazu (fig. 3a), en El Rosario las imágenes religiosas en escultura y en altorrelieve están policromadas y estofadas. Los soportes del cuerpo son cuatro largos estípites con peanas que se proyectan desde la parte central de los estipos; en este altar se miran vacías, mientras que en Aránzazu están ocupadas por esculturas de arcángeles.

Al centro del retablo sobresale un fanal que resguarda la imagen de vestir de la Virgen del Rosario. Abajo de la vitrina se encuentra el sagrario, que presenta una puerta pequeña a diferencia de Aránzazu, donde el largo del acceso abarca la altura del banco. En forma similar las puertas están resguardadas por dos angelitos de cuerpo completo dispuestos en las esquinas superiores. Asimismo, 
el banco muestra una serie de figuras de medio cuerpo en altorrelieve enmarcadas en medallones, cuatro tetralobulados y dos ovalados. En los interestípites laterales sobresalen pilastras-nicho donde se posan esculturas de tamaño natural; entre cada par, en un nivel superior, se mira un medallón lobulado con una figura de medio cuerpo en altorrelieve. Como en Aránzazu, una notable cornisa separa el cuerpo y el remate del retablo. Éste se inscribe en un arco de medio punto y presenta dos estípites que separan tres pilastras-nicho. En El Rosario faltan las esculturas pequeñas que en Aránzazu ocupan los extremos del remate, pero el espacio se conserva, por lo que es probable que se hayan perdido. De igual manera, una figura central de medio cuerpo en altorrelieve corona el conjunto.

En su ornamentación, el retablo de la Virgen del Rosario exhibe mayor profusión de formas vegetales y roleos que el retablo de Aránzazu de Guadalajara. Mas sin duda ambas obras se basaron en el mismo proyecto y es muy probable que las realizaran distintos talleres, ya que se aprecian diferencias en el tipo de talla de los relieves decorativos, varían los rasgos de las figuras religiosas y en El Rosario hay mayor proyección de los elementos del retablo.

Por otra parte, en su estudio de las iglesias barrocas de Sinaloa, Elisa Vargaslugo apunta algunos vínculos con Guadalajara. Aun cuando no menciona la capilla de Aránzazu, señala el parecido de la portadas con apoyos salomónicos de los templos del Rosario y de San Francisco de Guadalajara, y plantea que el remate mixtilíneo de la fachada tapatía de San Felipe Neri pudo servir de inspiración en la Concordia. En tanto, como elementos más originales y distintivos de la arquitectura de estas dos iglesias sinaloenses identifica el torreón-escalera (cubo cilíndrico de la escalera en forma de caracol que conduce al coro y que se ubica en una fachada lateral) y, acerca de los retablos del Rosario y de Copala, las estípites-peanas. 55

Estos dos elementos están presentes en la capilla de Aránzazu y corroboran los nexos entre Sinaloa y Guadalajara a través de la comunidad de origen vasco que ahí se asentó. Asimismo, se advierten aportaciones formales de la región noroccidente al arte colonial novohispano. Los datos históricos indican que los vínculos artísticos entre la poblaciones del Rosario y de Guadalajara se produjeron no sólo a través de las relaciones económicas y administrativas que había entre Nueva Vizcaya y Nueva Galicia; en este caso se puede asegurar que fue muy importante el sentido de asociación propio de los vascongados. 
En la ciudad de Guadalajara, Francisco Xavier Vizcarrra tenía su licencia de minero, ${ }^{56}$ y ahí mismo contrajeron matrimonio él y algunos de sus hijos. ${ }^{57} \mathrm{Al}$ respecto, Olveda escribe que la temprana vocación mercantil de la capital novogalaica se manifestó especialmente a través de sus características sociales; así:

Los estudios recientes destacan la importancia que adquirió Guadalajara desde el siglo xvi por haber proporcionado servicios de índole política, religiosa, económica y educativa. Pero aparte de estos atractivos, tuvo otro incentivo que sedujo a las familias ricas de otras regiones: el ser un lugar idóneo para contraer buenos matrimonios, ya que aquí radicaban funcionarios, comerciantes, hacendados y mineros poderosos e influyentes. ${ }^{58}$

En la fundación del Rosario y de Guadalajara la presencia de los vascos fue determinante, y durante los dos siglos posteriores el incremento de esta comunidad en la región noroeste desempeñó un papel esencial en el desarrollo económico de la zona y en su definición social. Como atestiguaremos a continuación, las relaciones personales estrechas entre los vascos-novohispanos y el seguimiento de sus actividades lucrativas son una clave para el conocimiento del arte virreinal de esta región.

De nuevo la investigación en documentos originales de Erick van Young sobre el medio rural de Guadalajara durante las postrimerías del virreinato aporta ahora la historia de Francisco Xavier Vizcarra. De ascendencia vasca, como se dijo, nació en El Rosario alrededor de 1727. Su padre, Juan Antonio Vizcarra, era originario de Guadalajara, tal vez asociado con el capitán Antonio Vizcarra. Éste era un hacendado prominente que poseía la hacienda de Miraflores a principios del siglo XVIII. Recordemos que dicha propiedad fue adquirida en I782 por José Ignacio Basauri. Francisco Xavier Vizcarra se asoció con Manuel Calixto Cañedo en la explotación de las minas de los Reales del Rosario y de Pánuco. La fortuna acumulada, su apoyo a la actividad misionera en Sonora y la construcción de la iglesia del Rosario lo convirtieron en marqués de Pánuco en 1772 .

56. Ibid., p. 70, apud Ricardo Ortega y Pérez Gallardo, Historia genealógica de las más antiguas familias de México, México, Imprenta de A. Carranza, 1908, p. 2.

57. Van Young, op. cit., pp. 302-306.

58. Jorge Olveda, "Mineros y comerciantes vascos en el sur de Sinaloa", en Jorge Olveda (coord.), Los vascos en el noroccidente de México. Siglos XVI-XVIII, Zapopan, El Colegio de Jalisco, 1988, pp. 93-106. 
Vizcarra invirtió sus ganancias en la minería para comprar cuatro de las principales haciendas de la región de Guadalajara, las cuales abastecían a la ciudad de carne y de trigo. En 1769 adquirió las haciendas de Toluquilla y de Estipac, esta última en Cocula, y en I78I la de Santa Cruz, ubicada en el valle de Toluquilla, y la ex hacienda jesuita La Sauceda, también en Cocula. Asimismo, alrededor de 1780 se hizo de la hacienda de Palmito Verde, en las cercanías del Rosario, con el fin de abastecer de ganado y víveres a sus minas; dicha hacienda vendía también ganado a la ciudad de México. Poseía además minas en Villa de San Sebastián, era dueño del rancho La Magdalena y de casa, bienes y tienda en Guadalajara. Con alta probabilidad la fortuna del marqués de Pánuco fue la mayor que hubo en esta ciudad y su riqueza agrícola la más grande que se acumulara desde el siglo XviI.

En su primer matrimonio, con Josefa del Carrillo y Pesquera, tuvo tres hijas y un hijo; éste y una de sus hermanas hicieron vida religiosa en Guadalajara. Las otras dos se casaron, una con Ramón Fernández Barrena y la otra con el abogado Juan Francisco Corcuera, ambos destacados comerciantes-hacendados de origen español residentes en Guadalajara. Al existir grandes dotes de por medio y a través de este tipo de alianzas matrimoniales, alrededor de Vizcarra se crearon otras fortunas y extendieron latifundios.

Después de enviudar, el 5 de febrero de 1777 Francisco Xavier Vizcarra se casó con María Ana de Arzubialde, hija del vasco Agustín de Arzubialde, quien fue el primer socio mercantil de Tomás Basauri. Agustín de Arzubialde falleció en 1776 , cuando era uno de los principales comerciantes de Guadalajara y miembro del cabildo; heredó a su hija un mayorazgo. En 1788 murió el primer marqués de Pánuco y su patrimonio fue repartido entre sus familiares. ${ }^{59}$

Aun cuando Vizcarra no aparece entre los fundadores de la cofradía de Aránzazu, es posible que después se hiciera cofrade, puesto que residía en Guadalajara. Lo que sí es seguro es que conocía a Tomás Basauri y a su familia, en vista de su contemporaneidad, su ascendencia vasca, los vínculos sociales y económicos tan cercanos que mantuvo esta comunidad y que Vizcarra contrajo matrimonio con la hija del primer socio mercantil de Basauri. A partir de estos datos y principalmente de las similitudes formales entre las iglesias que patrocinaron Basauri y Vizcarra, cabe afirmar que el retablo mayor de Aránzazu fue el modelo para construir los altares mayores del Rosario y asimismo el de Copala, y quizá también contrataron al mismo arquitecto retablista. 
I06

VERÓNICA HERNÁNDEZ DÍAZ

El retablo de San José del templo de Copala es de dimensiones menores y de factura mucho más sencilla que los otros dos. No obstante haberse modificado, su estructura es idéntica a la de los retablos centrales de Aránzazu y del Rosario. De los dos estípites inferiores también sobresalen peanas y sus paredes están casi lisas, pero en las bandas que acompañan el marco del retablo se observan relieves vegetales y el distintivo reticulado. Por su parte, Vargaslugo también distingue que los retablos del Rosario y de Copala son obra del mismo taller. ${ }^{60}$

\section{El retablo de la Virgen de la Candelaria de la hacienda del Cabezón, Ameca, Jalisco}

Entre los datos históricos de Francisco Xavier Vizcarra surge el nombre de Manuel Calixto Cañedo, su socio en la industria minera de Sinaloa. Cañedo conformó el último gran mayorazgo del siglo xviı en Guadalajara al poseer las haciendas del Cabezón, La Vega, Buenavista, La Calera y sus tierras aledañas, todas en la fértil área de Ameca, cercana al volcán de Tequila. Su fortuna provino, al igual que la de Vizcarra, de la explotación de minas en El Rosario. ${ }^{61}$ Un descendiente del linaje Cañedo anota que Manuel Calixto financió, junto con Vizcarra, la construcción y el adorno de la iglesia del Rosario; precisa que ambos obtuvieron en Guadalajara, antes de 1756 , sus licencias de minero y que su sociedad terminó en 1765 . A partir de este año Cañedo se estableció en la ciudad de Guadalajara y compró una lujosa residencia ubicada a espaldas de la catedral (hoy desaparecida), así como las haciendas antes dichas. ${ }^{62}$

La actual ex hacienda del Cabezón preserva en su capilla un retablo barroco (fig. 7a). En I765 Manuel Calixto Cañedo adquirió esta hacienda; después de su muerte, ocurrida en $1793,{ }^{63}$ sus descendientes la conservaron hasta que ocurrió la repartición de tierras a causa de la Reforma agraria. ${ }^{64}$ El diseño de la fachada de la capilla difiere de las portadas antes vistas, pero, de modo interesante, en el costado izquierdo sobresale, al igual que en Aránzazu, El Rosario y Concordia, el cilindro que aloja la escalera de caracol que conduce al coro y

6o. Vargaslugo, op. cit., p. 72.

6r. Van Young, op. cit., pp. 236 у 237.

62. Jorge Palomino Cañedo, La casa y mayorazgo de Cañedo de Nueva Galicia, México, Atenea, I947, pp. 39-4I.

63. Ricardo Lancaster Jones, "Haciendas de Jalisco y aledaños: fincas rústicas de antaño, I506I82I", tesis de maestría, Alburquerque, University of New Mexico, I973, p. 91.

64. Palomino, op. cit., pp. 486 y 49 I. 
al campanario. El interior de la capilla del actual poblado del Cabezón es una nave rectangular cuyas bóvedas están decoradas con las nervaduras típicas de la región. El altar se dedica a la Virgen de la Candelaria, no es propiamente estípite y aunque el cuerpo interior presenta columnas, exhibe fuertes rasgos de la corriente anástila por lo que cabe pensar que fue realizado a finales del siglo XVIII. Su concepción plástica se asemeja notablemente al retablo anástilo de San José de la capilla de Aránzazu.

El retablo de la Candelaria es de madera dorada, está compuesto por un banco y dos cuerpos separados por una ancha cornisa moldurada; se miran tres calles: la central es más ancha. La parte superior se inscribe en un marco poligonal de medio punto con roleos en sus extremos, los cuales alcanzan la mitad del segundo cuerpo. En los cuatro soportes del primer cuerpo de las formas bulbosas alternadas con cornisas; en el segundo cuerpo se aprecian cuatro pilastras decoradas con guirnaldas. En la predela, bajo los arranques de los apoyos, hay cuatro esculturas doradas y policromadas, en las laterales figuran leones y en las del centro pelícanos. Entre cada par, se mira en altorrelieve pintado, un joven de medio cuerpo asomándose entre guirnaldas y roleos, sobre un fondo con el mismo tipo de reticulado que adorna el retablo mayor de Aránzazu (fig. 7b).

Los soportes del primer cuerpo se decoran con rostros de ángeles; en la base destacan entre guirnaldas los relieves de medio cuerpo de los cuatro evangelistas con su atributo particular. De izquierda a derecha vemos a Lucas, Juan, Mateo y Marcos. Como parte de la modalidad anástila, la calle central del retablo exhibe ornamentación abundante en las pilastras-nicho: molduras que se curvan y forman espirales y motivos vegetales tipo rococó, así como esculturas de ángeles de cuerpo completo.

En un pequeño fanal resalta la imagen titular, una figura de vestir coronada. Sobre una peana arriba de la Candelaria, se encuentra la escultura casi de tamaño natural de san José cargando al niño Jesús. A su alrededor se disponen los siete santos arcángeles alojados en las pilastras-nicho de los intercolumnios. Son esculturas policromadas de tamaño natural; cuatro están en el primer cuerpo: en la calle que vemos a la izquierda está Sealtiel y arriba Uriel, y en la sección tercera, Jehudiel sobre Barachiel. En el cuerpo superior del conjunto se mira, de izquierda a derecha, a Gabriel, Miguel y Rafael. Cada arcángel se distingue por su atributo particular y porque lleva su nombre en la plataforma a la que está sujeto. Algunas de estas bases llevan inscrita la fecha de I863, año de creación de las esculturas. Dios Padre corona el conjunto; es una figura de medio cuerpo en altorrelieve sobre la moldura superior. 
IO8

VERÓNICA HERNÁNDEZ DÍAZ

De acuerdo con Gómez Arriola, es posible que una crisis financiera impidiera a la familia Cañedo proveer de esculturas al retablo en el momento de su conclusión y sólo hasta I863 estuvieron en condiciones de hacerlo; quizás ello explica que su altura sobrepase el formato de los nichos. ${ }^{65}$ Con excepción de la imagen principal de la Candelaria, que fue traída a fines del siglo xvi por Pedro Cabezón, el primer dueño de la hacienda. ${ }^{66}$

La decoración general con relieves vegetales y roleos de apariencia rococó y los soportes con altorrelieves de santos recuerdan al retablo de San José de la capilla de Aránzazu. En tanto, el detalle del reticulado que sirve de fondo a las figuras del banco del retablo, ubicadas bajo los soportes (fig. 7b), lo emparientan con el retablo mayor de Aránzazu.

En páginas anteriores se indicó el parecido que hay entre la imaginería de los retablos mayor y de San José de la capilla de Aránzazu. Ahora, en relación con el retablo de la Candelaria, cabe plantear como hipótesis que los tres retablos fueron realizados por un mismo taller debido a que guardan similitudes en diseño y en los trabajos de carpintería y entallado. No obstante, sólo es oportuno afirmar que existieron relaciones de trabajo y fuertes influencias entre los artistas que participaron en la creación de los retablos: se trata de obras formalmente asociadas, contemporáneas, realizadas dentro de la misma región, y cuyos patrocinadores mantenían vínculos sociales cercanos.

\section{Domingo Casillas, dorador de retablos}

Palomino Cañedo escribe, sin referir su fuente, que el retablo de la hacienda del Cabezón data de fines del siglo xviı y fue hecho por Domingo Casillas, a quien atribuye el dorado de los altares colaterales de la iglesia de San Francisco de Asís de Guadalajara. ${ }^{67}$ El nombre de este artista aparece en el libro titulado La calle de San Francisco; su autor, Cornejo Franco, cita un documento del 24 de noviembre de 1749 en donde consta que la Diputación de Comercio y Real Aduana contrató al "maestro de dorador y vecino de la ciudad Domingo Casillas" para dorar un retablo de la capilla de la Tercera Orden, ubicada en el antiguo convento franciscano en Guadalajara. Al ser este suceso contemporáneo

65. Comunicación personal en mayo de 1998.

66. Palomino, op. cit., p. 483.

67. Ibid., p. 489. Para su obra, el autor consulta el archivo familiar; sin embargo en este caso no menciona haberlo hecho. 
de la construcción del templo de Aránzazu, Cornejo considera que Domingo Casillas pudo dorar retablos en Aránzazu. ${ }^{68}$

Sobresale el hecho de que Palomino atribuya a Casillas no sólo el dorado, sino también la autoría del retablo de la hacienda del Cabezón; de ser así, el artista desarrolló su actividad retablística y, además de dorar, diseñó y construyó altares. Debido a la coincidencia de datos es probable que efectivamente Domingo Casillas trabajara en la capilla de Aránzazu.

El retablo del Dulce Nombre de Jesús, Amacueca, Jalisco

Al grupo de artistas que participaron en los altares de Aránzazu y de la Candelaria podría atribuirse la realización de otro retablo en Amacueca. Se dedica al Dulce Nombre de Jesús, pertenece a la modalidad del barroco estípite y su factura es anterior a la de los retablos vistos (fig. 8a). El templo donde se ubica forma parte de un convento franciscano y tal vínculo pudo originar la contratación del mismo taller.

El municipio de Amacueca está en la región sureste de Jalisco, y su convento e iglesia fueron fundados en $1547 .{ }^{69} \mathrm{La}$ fachada de la iglesia del Dulce Nombre de Jesús es de estilo salomónico y sigue el modelo de la portada del templo de San Francisco de Guadalajara. El 23 de octubre de 1749 un temblor destruyó la iglesia, un retablo colateral, varios lienzos pintados y el convento. El altar mayor permanece con modificaciones debido a que resultó afectado en su calle central; se perdió el remate de medio punto que la coronaba y parte de la imaginería.

El retablo del Dulce Nombre de Jesús se compone de sotabanco, banco, un cuerpo y remate; sólo están dorados los ornamentos sobresalientes. Según fray Luis Palacio la obra fue repintada, y así se observa en el fondo plano del retablo. En el cuerpo del conjunto cuatro estípites dividen tres calles de igual tamaño; en su parte media los estipos presentan altorrelieves policromados y estofados

68. Cornejo Franco, op. cit., p. 64.

69. Los datos históricos del convento y parroquia de Amacueca se tomaron del Santuario de Amacueca. Fuentes de su historia. Relato. Descripción, obra escrita por fray Luis del Refugio del Palacio con base en datos proporcionados en diferentes fechas por fray Antonio Tello (I652), fray Nicolás Ornelas (I719-1722), Matías de la Mota Padilla (1742) y principalmente fray Francisco Mariano de Torres (1755). De este último, Palacio transcribe un ensayo titulado Luza americano, Betel cristiano, escrito alrededor de 1755 , que aporta la mayoría de la información acerca de los retablos con que contaba la iglesia de Amacueca. La obra de Palacio se publicó en Guadalajara como suplemento de ET-CAETERA, núms. 7-8, julio-diciembre de 1955 . 
de figuras de medio cuerpo surgiendo entre guirnaldas. En el remate hay dos estípites arriba de los dos centrales de la sección inferior; una moldura ancha con numerosos quiebres delimita la parte superior del retablo.

En los intercolumnios de las calles laterales se observan pilastras-nicho enmarcadas por gruesas molduras mixtilíneas. El fondo de las pilastras es plano y sus peanas sobresalientes; la altura de los nichos es mediana, casi de tres cuartos de una figura de tamaño natural. En el cuerpo de cada calle lateral se miran dos nichos y en el remate uno. La figura principal, que es grande, reside en una vitrina en la parte central superior. La decoración de la obra es abundante, consiste en relieves que imitan formas vegetales, roleos y rostros de ángeles, algunos de los cuales voltean hacia la parte central del retablo. La talla de estos elementos es fina y de gran calidad. Además del Cristo crucificado, en la iconografía original se incluyen los altorrelieves de religiosos que ocupan la parte media de los cuatro estipos del cuerpo del retablo (fig. 8b).

Los rasgos comunes entre los retablos de San José de la capilla de Aránzazu y el del Dulce Nombre de Jesús son el diseño de los relieves fitomorfos y roleos ornamentales, los relieves antropomorfos sobresalientes entre las guirnaldas de los estipos (véanse figs. $5 \mathrm{~b}$ y $8 \mathrm{~b}$ ) y, de modo especial, la manufactura minuciosa de los rostros angelicales y la actitud de algunos que voltean hacia el centro del retablo en el caso de Amacueca, o hacia los lados en el de San José. También guardan parecido las anchas molduras poligonales que enmarcan las pilastrasnicho de ambos conjuntos. De tal manera, cabe pensar que las mismas manos diseñaron y entallaron la decoración de estos dos retablos, aunque se advierte que el diseño de las estructuras es de autoría distinta.

En I749, año en que el santuario de Amacueca fue arruinado por un temblor, apenas se había iniciado la construcción de la capilla de Aránzazu. Las consideraciones sobre las similitudes formales entre las obras mencionadas podrían indicar que un mismo taller de artistas retablistas trabajó durante un periodo prolongado, al menos todo el siglo XvirI. De ser así, cabe apuntar que la cohesión social de los grupos de artistas, así como las influencias formales que entre ellos mismos ejercían y se manifestaban expresamente en sus obras, perduraban a la par que las relaciones entre los pudientes hacendados y las órdenes religiosas.

\section{La obra retablística del arquitecto Francisco Martínez Gudiño}

Otra vía para el estudio interregional del arte colonial a partir de los retablos de la capilla de Aránzazu de Guadalajara surge de datos expuestos por José Rodol- 
fo Anaya Larios; sin embargo, las evidencias formales de las obras no son tan claras como en los casos anteriores. Anaya trata sobre el arte queretano y en relación con ello apunta que el artista tapatío Francisco Martínez Gudiño hizo un retablo en la capilla de Aránzazu del convento franciscano de Guadalajara. No precisa cuál de los tres retablos. Según Anaya, la producción artística de Martínez Gudiño fue muy extensa, comprende obras de arquitectura, escultura y retablística y abarcó las ciudades de Querétaro, Morelia, San Miguel de Allende, Celaya y, en Zacatecas, la de Bernadez. Añade que formó, junto con Mariano de las Casas y Pedro José de Rojas, una trilogía de artistas y que murió en Valladolid, hoy Morelia, en abril de $1775 .^{70}$

Martínez Gudiño nació en Guadalajara en I708, se sabe que en I 733 contrajo matrimonio y luego vivió en Valladolid. Entre 1748 y 1749 se instaló en la ciudad de Querétaro y en 1752 estaba construyendo el beaterio de Santa Rosa de Viterbo. ${ }^{71}$ La revisión de los retablos creados por este arquitecto-ensamblador apunta a un artista prolífico y cambiante que representó en Querétaro la última modalidad del barroco, la anástila, y realizó obras neoclásicas en Morelia. No obstante, casi no se advierten rasgos que recuerden a los retablos de la capilla de Aránzazu: la estructura varía y la ornamentación también.

Trataremos en particular los retablos anástilos de la iglesia de Santa Clara en Querétaro, realizados hacia 1763-1766. ${ }^{72}$ Estos colaterales se dedican a La Dolorosa, a la Virgen de Guadalupe, a Juan María Vianney y a la Inmaculada Concepción. En el primero se mira, al igual que en el retablo principal de Aránzazu, el fondo trabajado a manera de relieve, pero el diseño difiere: en Aránzazu es claramente reticulado y en Santa Clara aparece en forma de petatillo. En tanto,

70. José Rodolfo Anaya Larios, "Introducción”, en Guillermo Boils Morales, Arquitectura y sociedad en Querétaro (siglo XVIII), Querétaro, Universidad Nacional Autónoma de México-Instituto de Investigaciones Sociales/Archivo Histórico del Estado, 1994, pp. XXIV-XXXIII. Anaya indica que los datos forman parte de un estudio introductorio que acompañará la edición del Inventario de bienes de Francisco Martínez Gudiño, publicación del Archivo Histórico del Estado de Querétaro y de la Universidad Autónoma de Querétaro. Sin embargo, no he encontrado que la obra haya salido a luz pública. Por otra parte, acerca de la muerte de Martínez Gudiño, Boils Morales anota que estuvo trabajando en Querétaro desde 1750 hasta 1795, año en que ubica el deceso del artista, op. cit., p. 6I.

71. Ana Luisa Sohn Raeber, "Francisco Martínez Gudiño. Arquitecto-ensamblador”, Anales del Instituto de Investigaciones Estéticas, México, Universidad Nacional Autónoma de México-Instituto de Investigaciones Estéticas, núm. 65, 1994, pp. I80 y I8I.

72. Mina Ramírez Montes, "Retablos”, en Juan Antonio Isla Estrada (coord.), Querétaro, ciudad barroca, México, Gobierno del Estado de Querétaro, 1988, pp. 157-I92. 
en el guardapolvos del retablo bajo de Juan María Vianney hay relieves vegetales cuya parte interior lleva un diseño cuadriculado, similar al del retablo de la Virgen de Aránzazu. Por este detalle y por la fecha en que los retablos fueron erigidos (década de 1760), se podría suponer que Francisco Martínez Gudiño fue el autor del mayor de Aránzazu; sin embargo, en el de La Dolorosa y en sus otras obras se observa un estilo y una calidad plástica muy diferentes de la de los altares de Aránzazu y de los demás sitios aludidos. Por tales razones, me resulta difícil considerar a Martínez Gudiño como el arquitecto diseñador de alguno de los retablos vistos de Jalisco y Sinaloa, aunque sí cabría la posibilidad de su participación dentro del taller que construyó el retablo de la Virgen de Aránzazu en Guadalajara.

Sólo conviene agregar que el retablo de la Candelaria, en la ex hacienda del Cabezón, presenta en la parte superior central esculturas de ángeles de cuerpo completo, que al parecer sostenían amarres de cortinajes (fig. 7a). Este tipo de figuras se aprecia en algunos de los retablos de Martínez Gudiño en Querétaro.

\section{Consideraciones finales}

En Guadalajara, la capilla de la Virgen de Aránzazu sobresale por conservar los únicos retablos barrocos dorados que existen en la localidad. De modo separado, la historia de la familia vasca que patrocinó su construcción únicamente ha sido tratada en relación con indagaciones de carácter económico y social. Por su parte, este trabajo revisa los dos temas anteriores y aporta un contexto más amplio para conocer el arte novohispano en el noroccidente mexicano. Así, se muestra un panorama de relaciones interregionales diversas a partir de los retablos de la capilla de Aránzazu de Guadalajara, que debe profundizarse con estudios diversos. Algunas vías para ello se apuntan ya en la presente investigación.

La importancia de la capilla de Aránzazu se aprecia por ser un conjunto que integra artes diversas en obras de alta calidad: arquitectura, escultura, relieve, pintura y estofado. Asimismo, por sus múltiples valores históricos, pues se trata del único recinto de la ciudad que preserva su interior casi como lucía en la segunda mitad del siglo XviII, de un vestigio notable de lo que fue el legendario y espléndido convento de San Francisco, fundado en el siglo xvi y destruido casi totalmente a partir de la Reforma, y, además, de un monumento emblemático de la sobresaliente presencia vasca en la Nueva Galicia y en el noroccidente del país. 
Aquí se ha expuesto un análisis histórico-artístico con base en indagaciones documentales y en la información que las obras de arte aportan por sí mismas. Como resultado, se localizaron fuentes desconocidas, como las actas relativas a la fundación de la cofradía de Aránzazu en Guadalajara, que datan de 1774- 1776, y dos inventarios del templo de San Francisco de Asís de i826 y 19I4. Además de los retablos de la capilla de Aránzazu, se abordaron los de otros sitios de Jalisco y Sinaloa. Los argumentos integrados permitieron plantear varias hipótesis acerca de su realización. De tal manera, cabe suponer que un mismo grupo de artistas, cada uno especializado en las tareas múltiples que implicaba la creación de un retablo, trabajó en varias de las obras religiosas que erigió la comunidad franciscana a través del tiempo y en lugares distintos. No obstante, ahora sólo es evidente que fueron contratados de modo frecuente por los devotos y pudientes miembros de la oligarquía para la realización de altares en sus propiedades.

Los vínculos sociales y económicos que mantenía la elite desempeñaron un papel determinante en la elección de los artistas. Es muy probable que los retablos mayor y de San José de la capilla de Aránzazu, el de la Virgen de la Candelaria en la ex hacienda del Cabezón y, en Sinaloa, el retablo del Rosario y el altar de Copala, hayan sido diseñados por el mismo arquitecto-retablista. En tanto, su manufactura involucraría a talleres distintos, aunque en el caso de la imaginería de los retablos de Aránzazu y de San José, hay similitudes formales que incluso podrían mostrar las huellas de las mismas manos. Es posible considerar también que en el retablo del Dulce Nombre de Jesús, en Amacueca, trabajó el mismo entallador del retablo de San José, en vista del parecido que presentan los rostros de ángeles y los relieves de religiosos.

Por último, a través de esta investigación, se establece con certeza la vinculación artística en la región noroccidental durante el virreinato, en particular entre las poblaciones del Rosario, Sinaloa y el área de Guadalajara, Jalisco, como resultado de las relaciones sociales conformadas por un grupo que mostró una intensa cohesión religiosa y económica: los vascos. \$ 